\title{
Melastomataceae na Reserva Ecológica de Macaé de Cima, Nova Friburgo, Rio de Janeiro, Brasil. II - Leandra (Miconieae)
}

Melastomataceae in the Ecological Reserve of Macaé de Cima, Nova Friburgo, Rio de Janeiro, Brasil. II - Leandra (Miconieae)

José Fernando A. Baumgratz ${ }^{1,3} \&$ Maria Leonor D’El Rei Souza ${ }^{2}$

\begin{abstract}
Resumo
Apresenta-se o estudo taxonômico do gênero Leandra na Reserva Ecológica de Macaé de Cima, tendo sido reconhecidas 35 espécies e três novos sinônimos, além da designação de três lectótipos. Constam uma chave para a identificação das espécies, descrições, ilustrações, dados de distribuição geográfica e comentários sobre particularidades taxonômicas e morfológicas. Leandra aspera, L. atroviridis, L. eriocalyx, L. laxa, L. mollis, L. multisetosa, L. sphaerocarpa e L. tetragona são endêmicas de Macaé de Cima e, juntamente com $L$. altomacaensis, L. breviflora, L. hirta var. hirta e L. magdalenensis, endêmicas do estado fluminense. Leandra altomacaensis, L. glazioviana, L. riedeliana e L. truncata representam novas ocorrências para a Reserva. Leandra aspera, L. atroviridis, L. multisetosa, L. sphaerocarpa e L. tetragona estão sendo ilustradas pela primeira vez.
\end{abstract}

Palavras-chave: endemismo, flora, Mata Atlântica, taxonomia, Unidade de Conservação.

\begin{abstract}
A taxonomic study of Leandra in the Ecological Reserve of Macaé de Cima is presented. The genus is represented by 35 species. Three new synonyms are recognized and three lectotypes are designated. A key to the identification of the taxa are also provided, as well as descriptions, illustrations, geographic distribution data and comments about taxonomic and morphological particularities. Leandra aspera, L. atroviridis, $L$. eriocalyx, L. laxa, L. mollis, L. multisetosa, L. sphaerocarpa, and L. tetragona are endemic to Macaé de Cima. These species and L. altomacaensis, L. breviflora, L. hirta var. hirta, and L. magdalenensis are endemic to the State of Rio de Janeiro. Leandra altomacaensis, L. glazioviana, L. riedeliana, and L. truncata represent new occurrences to the studied area. Leandra aspera, L. atroviridis, L. multisetosa, L. sphaerocarpa, and $L$. tetragona are ilustrated for the first time.
\end{abstract}

Key words: Atlantic Forest, Conservation Unit, endemism, flora, taxonomy.

\section{Introdução}

A Reserva Ecológica de Macaé de Cima tem sido assinalada como um reduto de diversidade e endemismo do ecossistema Mata Atlântica (Guedes-Bruni \& Lima 1994) e como um importante centro de riqueza para a família Melastomataceae, onde constitui o grupo com maior número de espécies, incluindo várias endêmicas (Baumgratz 1994, 1997; Guedes-Bruni \& Lima 1994; Baumgratz et al. 2001; Baumgratz et al. 2007).
Baumgratz et al. (2007) apresentaram os primeiros resultados sobre a diversidade taxonômica da família na Reserva, destacando a representatividade quali-quantitativa dos táxons. Nessa abordagem, incluem uma chave para a identificação dos 13 gêneros reconhecidos, a caracterização das cinco tribos para a área e o tratamento taxonômico das tribos Bertolonieae, Merianieae e Microlicieae, que englobam seis gêneros.

\footnotetext{
${ }^{1}$ Instituto de Pesquisas Jardim Botânico do Rio de Janeiro, R. Pacheco Leão 915, 22460-030, Rio de Janeiro, RJ, Brasil. Bolsista de Produtividade CNPq.

${ }^{2}$ Universidade Federal de Santa Catarina, CCB, Depto. Botânica, Campus Universitário, 88040-900, Santa Catarina, Brazil. delrei@ccb.ufsc.br

${ }^{3}$ Autor para correspondência: jbaumgra@jbrj.gov.br
} 
Dando continuidade a esses estudos na Reserva, propõe-se no presente trabalho o estudo do gênero Leandra (tribo Miconieae), que foi estimado por Baumgratz et al. (2007) a estar representado por 36 táxons, baseando-se em Cogniaux (1886, 1888, 1891), Glaziou (1908), coleções de herbários e revisões nomenclaturais. Apresentam-se uma chave analítica para identificação das espécies, descrições, ilustrações, dados de distribuição geográfica e particularidades dos táxons no ambiente, além de comentários sobre as espécies excluídas.

\section{Material e Métodos}

As características fisiográficas da Reserva citadas no texto encontram-se descritas em Lima \& Guedes-Bruni (1994), Lima \& Guedes-Bruni (1997) e Baumgratz et al. (2007).

O levantamento das espécies foi feito em literatura e nos herbários BR, C, F, FLOR, K, NY, P, R, RB e US (siglas de acordo com Holmgren et al. 1990).

Amostras de espécimes botânicos e dados dos ambientes, habitats e particularidades morfológicas e de fenologia foram obtidos também durante expedições científicas realizadas na área. O material coletado foi herborizado segundo técnicas usuais e incorporado ao Herbário RB e duplicatas encontram-se nos Herbários FLOR e US.

Adota-se o sistema de classificação da família Melastomataceae proposto por Renner (1993), com alterações de Clausing \& Renner (2001), conforme comentado por Baumgratz et al. (2007). Táxons infra-específicos não foram aceitos devido à inconsistência das circunscrições, exceto para $L$. hirta. As descrições das espécies foram restritas à Reserva e, quando necessário, complementadas com dados de literatura. Entretanto, para Leandra aspera Cogn., L. atroviridis Cogn., L. sphaerocarpa Cogn., L. tetragona Cogn. e L. truncata Baumgratz \& D’El Rei Souza apresentam descrições mais detalhadas, devido ao escasso conhecimento do táxon em literatura e de se dispor, até o momento, apenas de uma única coleção para análise.

Foram mencionados apenas sinônimos recentemente publicados ou pertencentes a táxons pouco abordados em literatura. Entretanto, outros sinômnimos podem ser consultados em Souza \& Baumgratz (2010).

Em coleções de A.F.M Glaziou, cujos períodos de coleta mostraram-se divergentes entre duplicatas, optou-se por incluir todas as informações obtidas, citando-se as mais recentes entre parênteses. Dados de distribuição geográfica e nomes populares foram obtidos em etiquetas de material de herbário, na literatura e/ou na comunidade local.

Utilizou-se conceitos de Radford et al. (1974) para a caracterização morfológica geral, os de Weberling (1988, 1989) e Briggs \& Johnson (1979), com modificações, para a descrição das inflorescências, e os de Baumgratz (1985) para a tipificação dos frutos e sementes. Na obtenção dos valores das distâncias suprabasais das nervuras acródromas foliares considerou-se apenas o par de nervuras mais interno.

\section{Resultados e Discussão}

De acordo com Baumgratz et al. (2007) e Souza \& Baumgratz (2009), Leandra caracteriza-se, principalmente, pelas inflorescências terminais, botões florais e pétalas de ápice agudo a acuminado, cálice bilobado, com lacínias externas geralmente conspícuas, às vezes reduzidas, e maiores que as internas, e pelos frutos carnosos. No presente estudo, apenas L. truncata apresenta as lacínias do cálice muito reduzidas, podendo as externas serem menores ou iguais às internas, possivelmente uma condição rara no gênero.

As folhas destituídas de formicárias e a presença de inflorescências pseudo-axilares também podem auxiliar no reconhecimento de Leandra (Cogniaux 18861888; Judd \& Skean 1991; Martin et al. 2008).

$\mathrm{Na}$ Reserva, Leandra mostra-se bem expressivo entre as Melastomataceae. O levantamento preliminar para o gênero, com base em coleções de herbários e em Cogniaux (1886, 1888, 1891), Glaziou (1908), Baumgratz (1994, 1997) e Baumgratz et al. (2001), apontou a ocorrência de 49 táxons (44 espécies e cinco variedades). Recentemente, Baumgratz et al. (2007), numa reavaliação taxonômica para a família, assinalaram Leandra como o segundo gênero mais numeroso na área, com 36 espécies. Entretanto, com base no presente estudo, Leandra se mantém nessa posição, porém representado por 35 espécies.

Considerando-se as 44 espécies inicialmente levantadas, 15 não foram mantidas por serem: (a) identificações equivocadas de $L$. confusa $C$ Cogn. para L. carassana (DC.) Cogn.; L. dubia DC. para L. hirta Raddi var. hirta; L. lancifolia (Cham.) Cogn. para $L$. aurea (Cham.) Cogn.; L. lutea Cogn. e L. sylvestris DC. para L. gracilis; e L. neurotricha Cogn. para $L$. quinquedentata; (b) nomes já sinonimizados, como L. alterninervia Cogn. (= L. regnellii (Triana) Cogn.) e L. membranifolia Cogn. (= L. acutiflora (Naudin) Cogn.), por Wurdack (1962); e L. sublanata (DC.) Cogn. (= L. carassana), por Souza \& Baumgratz 
(2004); e (c) prováveis sinônimos: L. attenuata Cogn., L. nutans Cogn., L. pectinata Cogn., $L$. quinquenodis (DC.) Cogn., L. schwackei Cogn. e L. trauninensis Cogn. Ainda nesse estudo, confirma-se a ocorrência de uma nova espécie para o gênero, L. altomacaensis Baumgratz \& D'El Rei Souza (Baumgratz \& Souza 2009a).

Leandra Raddi, Mem. Mat. Fis. Soc. Ital. Sci. Modena 18(2): 385, fig. 8. 1820.

Subarbustos a arvoretas; indumento variado, sempre com tricomas diminutos pubéruloglandulosos. Folhas sésseis ou pecioladas; lâminas membranáceas a cartáceas, 3-5(-7) nervuras acródromas, basais ou suprabasais. Inflorescências terminais, raro pseudo-axilares, brácteas e profilos persistentes ou não. Botões florais agudos a acuminados. Flores (4-)5-6-meras, sésseis a pediceladas; hipanto campanulado, tubuloso ou urceolado; zona do disco glabra ou pilosa; cálice gamossépalo, tubo inconspícuo, lacínias bilobadas, persistentes, as externas frequentemente maiores que as internas, raro menores ou iguais; pétalas alvas a rosadas, eretas a reflexas, lanceoladas, oblongosubuladas ou -triangulares, às vezes ovadas ou oblongo-obovadas, ápice agudo, atenuado e/ou acuminado, às vezes agudo-cuspidado, frequentemente apiculadas e glabras, raro pilosas; estames iguais a de dois tamanhos, filetes glabros, anteras alvas, róseas ou amarelas, retilíneas ou curvas, um poro terminal e/ou terminal-dorsal, conectivo prolongado ou não abaixo das tecas, inapendiculado ou apêndice dorsal reduzido, raro também com projeções ventrais; ovário total ou parcialmente ínfero, com prolongamento apical, 3-5-locular, glabro ou piloso; estilete glabro, raro estriguloso para a base; estigma capitado. Bacídios roxos a nigrescentes, subglobosos, globosos ou globoso-urceolados, polispérmicos; sementes obpiramidais, às vezes obovadas, testa lisa, aparentemente psilada ou papilosa.

Gênero neotropical, ocorrendo em regiões tropicais e temperadas, com cerca de 200 espécies, distribuindo-se desde o México e Antilhas até a Argentina, principalmente em formações campestres e florestas pluviais (Gröger 2001; Souza \& Baumgratz 2004; Baumgratz \& Souza 2007).

\section{Chave para identificação das espécies de Leandra na Reserva Ecológica de Macaé de Cima}

1. Plantas aparentemente glabras (tricomas diminutos pubérulo-glandulosos e glanduloso-pontoados, glanduloso-granulosos, lepidoto- ou furfuráceo-estrelados, setulosos e/ou estrigulosos).

2. Lâmina foliar com base nitidamente longo-decorrente ........................................ L. multiplinervis

2'. Lâmina foliar com base não-decorrente, raro curto-decorrente (em L. truncata).

3. Lâmina foliar com tricomas lepidoto-estrelados ........................................... L. altomacaensis

3'. Lâmina foliar com outros tipos de tricomas, não lepidoto-estrelados.

4. Lacínias externas do cálice $0,8-1 \mathrm{~mm}$ larg., ápice arredondado .................. L. atroviridis

4'. Lacínias externas do cálice 0,1-0,5 mm larg., ápice agudo, acuminado ou agudo- ou acuminado-apiculado.

5. Ramos apenas com tricomas diminutos pubérulo-glandulosos ou também glanduloso-pontoados.

6. Lâmina foliar glanduloso-pontoada e com tricomas diminutos pubéruloglandulosos, margem obscuramente ciliolada, nervuras secundárias e de ordem superior inconspícuas; lacínias externas do cálice ca. $1 \mathrm{~mm}$ compr., eretas a patentes; ovário 3-4-locular

L. sphaerocarpa

6'. Lâmina foliar apenas com tricomas diminutos pubérulo-glandulosos, às vezes face adaxial esparso-setulosa, margem nitidamente ciliolada, nervuras secundárias e de ordem superior conspícuas; lacínias externas do cálice 2-2,2 mm compr., reflexas; ovário 5-locular L. laevigata

5'. Ramos furfuráceo-estrelados e/ou glanduloso-granulosos.

7. Domácias em tufos de pêlos, axilar-primárias .............................. L. acutiflora

7'. Domácias marsupiformes, não em tufo de pêlos, ou ausentes.

8. Indumento dos ramos e hipanto apenas com tricomas glandulosogranulosos; cálice truncado-ondulado a -denticulado, lacínias externas até ca. $0,3 \mathrm{~mm}$ compr. L. truncata 
8. Indumento dos ramos e hipanto com tricomas furfuráceo-estrelados e geralmente obscurecidos por tricomas glanduloso-granulosos; cálice distintamente laciniado, nunca truncado, lacínias externas $0,7-1,9$ mm compr.

9. Lâminas foliares $1-5 \mathrm{~cm}$ larg., 3 nervuras acródromas, as laterais muito próximas ou confluentes às margens na porção basal L. quinquedentata

9.' Lâminas foliares 5,5-14,5 cm larg., 5 nervuras acródromas, as laterais nitidamente afastadas das margens na porção basal

L. barbinervis

1'. Plantas nitidamente pilosas.

10. Indumento constituído apenas de tricomas simples.

11. Lâmina foliar com base auriculada, geralmente amplexicaule

L. amplexicaulis

11'. Lâmina foliar com base de outras formas, nunca amplexicaule.

12. Inflorescências de glomérulos; brácteas involucrais.

13. Brácteas involucrais cedo caducas.

14. Indumento dos ramos, folhas, inflorescências e hipanto estriguloso .... L. aspera

14'. Indumento dos ramos, folhas, inflorescências e hipanto hirtelo-setoso

L. hirta var. hirta

13'. Brácteas involucrais persistentes.

15. Face abaxial das brácteas mais externas do invólucro floral, glabra ou tricomas restritos à região da nervura central L. fragilis

15'. Face abaxial das brácteas mais externas do invólucro floral, totalmente revestida por tricomas.

16. Ramos com tricomas iguais ou maiores que $2 \mathrm{~mm}$ de comprimento, patentes a reflexos, nunca adpressos; hipanto 4,8-6 mm compr. .... L. glazioviana

16'. Ramos com tricomas até $1,1 \mathrm{~mm}$ de comprimento, ascendentes, adpressos; hipanto 3,5-4 mm compr.

L. melastomoides

12'. Inflorescências não de glomérulos; brácteas não involucrais.

17. Indumento dos ramos, folhas, inflorescência e hipanto desprovido de tricomas glanduloso-granulosos; lacínias externas do cálice 1,7-2,1 mm compr. ... L. mollis

17'. Indumento dos ramos, folhas, inflorescência e hipanto constituído também de tricomas glanduloso-granulosos; lacínias externas do cálice ca. $0,5 \mathrm{~mm}$ compr. ......

10'. Indumento constituído de tricomas ramificados, às vezes, também de tricomas simples.

18. Plantas com tricomas glanduloso-granulosos.

19. Partes vegetativas e florais com tricomas dendríticos.....

L. magdalenensis

19'. Partes vegetativas e florais destituídas de tricomas dendríticos.

20. Nervuras acródromas da lâmina foliar $2-5 \mathrm{~mm}$ suprabasais; brácteas e profilos caducos L. riedeliana

20'. Nervuras acródromas da lâmina foliar 6-30 mm suprabasais; brácteas e profilos persistentes.

21. Ramos setulosos, tricomas esparsos ou restritos às regiões dos nós; face abaxial da lâmina foliar setulosa, tricomas restritos às nervuras acródromas; hipanto 2,8-3,2 mm compr. L. gracilis

21'. Ramos e face abaxial da lâmina foliar hirtelos, tricomas revestindo toda a superfície; hipanto 2-2,5 mm compr.

L. multisetosa

18'. Plantas desprovidas de tricomas glanduloso-granulosos.

22. Ramos nitidamente tetragonais-subalados

L. tetragona

22'. Ramos achatados, subcilíndricos e/ou cilíndricos, nunca alados.

23. Face abaxial da lâmina foliar com tricomas dendríticos.

24. Lâmina foliar com nervuras acródromas $11-30 \mathrm{~mm}$ suprabasais e tricomas dendríticos distintamente longo-pedicelados, com ramificações longas e adensadas no ápice

L. carassana

24'. Lâmina foliar com nervuras acródromas 3-6 mm suprabasais e tricomas dendríticos sésseis ou curto-pedicelados, com ramificações curtas e ao longo do eixo principal L. dasytricha 
23'. Face abaxial da lâmina foliar destituída de tricomas dendríticos.

25. Lâmina foliar com base decorrente ou agudo-cuneada.

26. Lâmina foliar com base decorrente, face adaxial plana, estrigulosa principalmente nas nervuras acródromas; lacínias externas do cálice 3-5 mm compr.; pétalas 3,5-5 mm compr.; filetes 2,5$3 \mathrm{~mm}$ compr.; estilete $8-10 \mathrm{~mm}$ compr. L. multiplinervis

26'. Lâmina foliar com base agudo-cuneada, face adaxial bulada, estrigulosa no limbo; lacínias externas do cálice 0,5-2,2 mm compr., pétalas 2-2,5 mm compr., filetes 1,3-2,2 mm compr., estilete 4,5-6,5 mm compr. L. regnellii

25'. Lâmina foliar com base não decorrente nem agudo-cuneada.

27. Face adaxial da lâmina foliar estrigulosa.

28. Pétalas pilosas

L. fallax

28'. Pétalas glabras.

29. Lacínias externas do cálice 1,3-1,8 mm compr., pétalas 2,6-2,7 mm compr.; anteras alvas; estilete 6-6,7 mm compr. L. eriocalyx

29'. Lacínias externas do cálice 2,8-3 mm compr., pétalas ca. 3,5 mm compr.; anteras amarelas; estilete ca. 7,3 mm compr.

27'. Face adaxial da lâmina foliar não estrigulosa.

L. purpurascens

30. Ramos, pecíolos e inflorescências apenas furfuráceo-estrelados; zona do disco formando um anel membranáceo L. breviflora

30'. Ramos, pecíolos e inflorescências furfuráceo-estrelados e com outros tipos de tricomas; zona do disco não formando um anel membranáceo.

31. Lâmina foliar bulada na face adaxial, foveolada na face abaxial.

32. Lâmina foliar com a face abaxial viloso-hirtela, nunca setuloso-setosa

L. aurea

32'. Lâmina foliar com a face abaxial setuloso-setosa, nunca vilosa .... L. foveolata 31'. Lâmina foliar plana e/ou ondulada em ambas as faces.

33. Anteras róseas.

34. Lâmina foliar com nervuras acródromas basais ou 1-2 mm suprabasais . L. aurea

34'. Lâmina foliar com nervuras acródromas 10-22 mm suprabasais ... L. laxa 33'. Anteras amarelas.

35. Hipanto 5-5,2 mm compr.; anteras 4,5-6 mm compr.; estilete $14,8-15 \mathrm{~mm}$ compr. L. xanthocoma

35'. Hipanto 2,8-4,2 mm compr.; anteras 2,1-3 mm compr.; estilete 5,8-8,5 mm compr.

36. Indumento dos ramos hirterlo, tricomas até $2 \mathrm{~mm}$ compr.; lâmina foliar com 3-5 nervuras acródromas L. purpurascens

36'. Indumento dos ramos hirsuto, tricomas 3-7,5 mm compr.; lâmina foliar com 5 e/ou 7 nervuras acródromas.

37. Lacínias externas do cálice 3-4 mm compr., as internas (1-)1,7$2 \mathrm{~mm}$ compr. L. nianga

37'. Lacínias externas do cálice 1-2(-3) mm compr., as internas $1-1,5 \mathrm{~mm}$ compr. L. xanthostachya

Leandra acutiflora (Naudin) Cogn. in Mart., Eichler \& Urban, Fl. bras. 14(4): 162. 1886.

Fig. 1a

Arbustos a arvoretas $1,2-5 \mathrm{~m}$ alt., aparentemente glabros; indumento esparsa a moderadamente furfuráceo-estrelado, tricomas cedo caducos. Folhas com pecíolo $(0,4-) 0,8-3,5 \mathrm{~cm}$ compr.; lâmina 5,5-15×2 -5,3 cm, membranácea, elíptica, às vezes obovada, base aguda a cuneada, à vezes obtusa, margem inteira, ápice agudo- ou atenuado-acuminado, face abaxial também esparsosetulosa nas nervuras acródromas; domácias em tufos de pêlos, axilar-primárias; 3-5 nervuras acródromas 8-30 mm suprabasais. Tirsóides; brácteas e profilos persistentes. Flores 5-meras; hipanto ca. 2,5 mm compr.; zona do disco setulosoglandulosa, glabrescente; lacínias do cálice eretas, 
as externas 0,2-0,3 × ca. 0,2 mm, ápice agudoapiculado, as internas 0,1-0,2 mm compr.; pétalas 3,3-3,6 mm compr., reflexas, triangulares, ápice atenuado, glabras; filetes ca. 1,5 mm compr.; anteras ca. 2,1 mm compr., elípticas, conectivo giboso no dorso, prolongado, inapendiculado; ovário 2/3ínferos, 3-locular, glabro; estilete 5-5,8 mm compr. Bacídios 5-10 mm compr.

Material examinado: 20.I.1888, fl., A.F.M. Glaziou 16915 (R, RB); 24.VIII.1986, fr., M. Leitman 133 (FLOR, RB); 9-12.V.1988, G. Martinelli et al. 12810 (RB); 4.IV.1989, fr., I.A. Araujo et al. 21 (FLOR, RB); 22.VI.1989, fr., M. Nadruz et al. 501 (RB); 29.VI.1989, fr., A. Amorim et al. 132 (CEPEC, FLOR, RB); 17-21.VII.1989, fr., $M$. Peron et al. 830 (RB); 15.VIII.1989, fr., C.M. Vieira et al. 35 (FLOR, RB); 17.VIII.1990, fr., J.F.A. Baumgratz et al. 464 (RB); 20.XI.1990, fl., J.F.A. Baumgratz et al. 484 (FLOR, RB); 17.I.1991, fr., J.F.A. Baumgratz et al. 536 (RB); 17.I.1991, fr., J.F.A. Baumgratz et al. 539 (CEPEC, FLOR, RB); 20.XII.1994, fl., M.L. Souza \& J.F.A. Baumgratz 1507 (FLOR, RB); 1.V.2001, fr., R.A.M. Tavares et al. 80 (FLOR, RB); 20.III.2007, fr., J.F.A. Baumgratz et al. 957 (FLOR, RB); 21.III.2007, fr., J.F.A. Baumgratz et al. 963 (MBM, RB).

Endêmica do Brasil, ocorrendo nos estados do Rio de Janeiro, São Paulo, Paraná e Santa Catarina. Na Reserva, cresce entre 700-1.400 m de altitude, em áreas dos Sítios Bacchus e Sophronites, Rio das Flores, Rio Macaé, próximo à entrada para a Pedra Bicuda, no interior de matas de encosta, ao longo de estradas, trilhas e margens de rios, geralmente em locais sombreados, às vezes ensolarados.

Facilmente reconhecida pelas folhas apresentando domácias em tufos de pêlos, axilarprimárias, na face abaxial.

Leandra nutans foi assinalada como ocorrente em Macaé de Cima (Glaziou 1908), porém considerase um provável sinônimo de L. acutiflora pelas semelhanças vegetativas e florais. Leandra nutans var. robertii Brade foi sinonimizada por Wurdack (1962) com L. acutiflora, que também assinalou ser esta espécie vegetativamente similar a L. nutans.

Leandra altomacaensis Baumgratz \& D'El Rei Souza, Kew Bull. 64(1): 167.2009. Fig. 1b-e

Arbustos com partes vegetativas aparentemente glabras; indumento dos ramos, pecíolos, inflorescências e hipanto esparsa a densamente furfuráceo-estrelado ou também esparso-setuloso. Folhas com pecíolo 1,2-2,5 cm compr.; lâmina 6-12 ×2,4-3,5 cm, membranácea, elíptica, base aguda a obtusa, margem onduladociliolada, ápice atenuado-acuminado, ambas as faces esparsamente lepidoto-estreladas, face adaxial glabrescente; 3 nervuras acródromas 4-7 mm suprabasais, além de duas marginais basais, inconspícuas. Metabotrióides; brácteas caducas ou não; profilos persistentes. Flores 5-meras; hipanto 2,4-2,5 mm compr.; zona do disco glabra; lacínias do cálice reflexas, as externas 0,6-0,7× ca. $0,2 \mathrm{~mm}$, crassas, agudo-apiculadas, as internas $0,3-$ 0,4 mm compr., membranáceas; pétalas 2,5-2,7 mm compr., reflexas, oblongas a oblongo-obovadas, ápice agudo-cuspidado, com curto apículo dorsal, glabras; estames de dois tamanhos, ante-sépalos com filetes 2,4-3 mm compr., anteras 2,5-2,6 mm compr., antepétalos com filetes $2-2,5 \mathrm{~mm}$ compr., anteras 2,12,4 mm compr., ambos com anteras oblongosubuladas, conectivo não prolongado, truncado ou emarginado na base, inapendiculado; ovário 3/4 ínferos, 4-locular, setuloso e estrelado-furfuráceo; estilete ca. 5,5 mm compr. Frutos maduros não vistos. Material examinado: 22.IX.1888(1889), fl., A.F.M. Glaziou 17533 (BR-2x - holótipo; P, R - isótipos de Leandra gracilis var. glazioviana $\mathrm{Cogn}$.).

Material adicional examinado: BRASIL. RIO DE JANEIRO: Santa Maria Madalena, Furquilha, XI.1932, fl. e fr., J. Santos Lima 120 (RB - holótipo de L. altomacaensis).

Não se conhece ainda a altura dos indivíduos de L. altomacaensis, pois esta informação não consta nas etiquetas das exsicatas examinadas. De acordo com Baumgratz \& Souza (2009a), trata-se de uma espécie rara na Reserva, não tendo sido recoletado outro espécime há mais de 100 anos. Neste trabalho, os autores assinalam que pela ausência de indumento glanduloso-granuloso e presença de tricomas lepidoto-estrelados na lâmina foliar, os espécimes analisados não correspondem a L. gracilis nem a outro táxon de Leandra, razão pela qual descreveram a nova espécie e consideram L. gracilis var. glazioviana como sinônimo de L. altomacaensis.

Leandra amplexicaulis DC., Prodr. 3: 153. 1828.

Fig. $1 f$

Arbustos a arvoretas 0,8-3 m alt., nitidamente pilosos; indumento dos ramos, pecíolos e inflorescências hispídulo-estriguloso. Folhas sésseis ou até $4 \mathrm{~mm}$ pecioladas; lâmina 8-21 ×2,6$6 \mathrm{~cm}$, papirácea a cartácea, elíptica, base auriculada, geralmente amplexicaule, margem crenuladociliolada, ápice agudo a acuminado, face adaxial estrigulosa, face abaxial estrigulosa nas nervuras e setulosa no restante da superfície; $3(-5)$ nervuras acródromas 10-30 mm suprabasais. Tirsóides de glomérulos; brácteas e profilos vinosos na frutificação, involucrais, persistentes, margem 

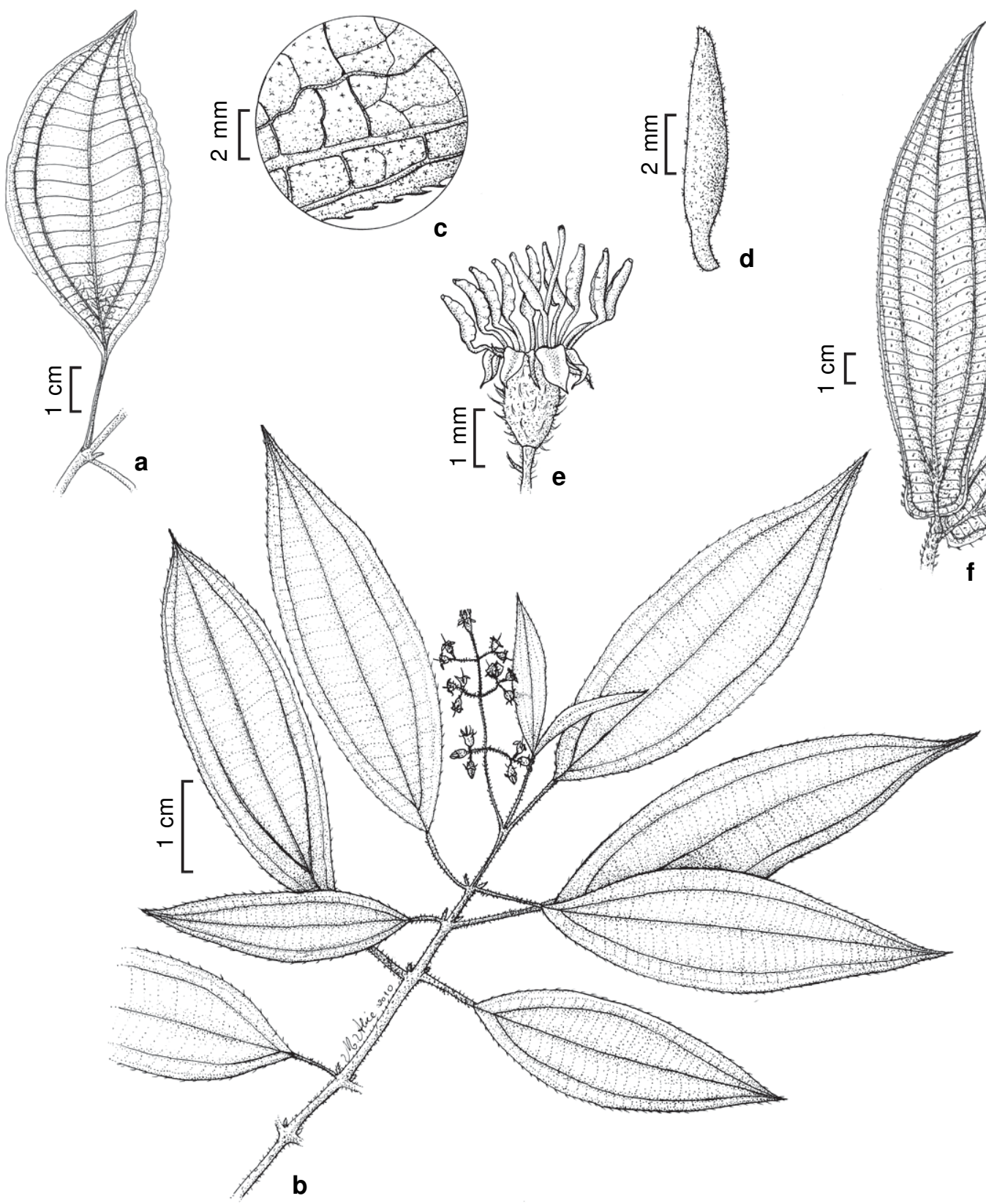

Figura 1 - a. Leandra acutiflora (Naudin) Cogn. - folha. b-e. Leandra altomacaensis Baumgratz \& D'El Rei Souza - b. ramo florífero; c. detalhe do indumento da face adaxial da folha; d. bráctea; e. flor. f. Leandra amplexicaulis DC. - folhas. (a Baumgratz et al. 539; b-e Glaziou 17533; f Baumgratz et al. 429).

Figure 1 - a. Leandra acutiflora (Naudin) Cogn. - leaf. b-e. Leandra altomacaensis Baumgratz \& D’El Rei Souza - b. flowering branch; c. detail of the foliar lamina indument on the adaxial surface; d. bract; e. flower. f. Leandra amplexicaulis DC. - leaves. 
ciliada, ambas as faces glabras. Flores 6-meras; hipanto 4-4,5 mm compr., densamente híspidoadpresso; zona do disco glabra; lacínias do cálice vinosas na frutificação, eretas, as externas ca. $1 \mathrm{~mm}$ compr., as internas 2,5-3 mm compr.; pétalas ca. 6 $\mathrm{mm}$ compr., eretas, estreitamente oblongotriangulares, ápice agudo-apiculado, glabras; estames de dois tamanhos, ante-sépalos com filetes 4-5,5 mm compr., anteras 4-4,5 mm compr., antepétalos com filetes ca. 4,5 $\mathrm{mm}$ compr., anteras 3,8-4 mm compr., ambos com anteras róseas, linear-atenuadas, extrorsamente falciformes, conectivo giboso, prolongado, apêndice calcarado ou truncado; ovário 1/3-3/5-ínferos, 4-locular, setuloso; estilete 8-12 $\mathrm{mm}$ compr. Bacídios ca. $6 \mathrm{~mm}$ compr.

Material examinado: 21.XII.1887, fl., A.F.M. Glaziou s.n. (P); 19.II(III).1888, fl., A.F.M. Glaziou 16825 (P, R); 7.VI.1989, fr., J.F.A. Baumgratz et al. 429 (FLOR, RB, US); 14-18.VIII.1989, fr., M. Peron et al. 845 (FLOR, RB); 11.IX.1990, fr., C.M.B. Correia et al. 153-B (RB); 16.I.1991, fl., J.F.A. Baumgratz et al. 519 (RB); 17.I.1991, fl., J.F.A. Baumgratz et al. 545 (RB); 19.II.1992, fl., T. Sampaio et al. (RB 299546); 6.VI.1993, fr., C.M. Vieira \& L.C. Gurken 267 (RB); 2.V.2001, fr., R.A.M. Tavares et al. 90 (FLOR, RB).

Endêmica do Brasil, ocorrendo em Minas Gerais, Espírito Santo, Rio de Janeiro, São Paulo, Paraná e Santa Catarina. Na Reserva, é encontrada entre 900-1.100 m de altitude, próxima ao Hotel Fazenda São João, Fazenda Ouro Verde, próximo ao Rio das Flores, Rio Macaé e Sítio Sophronites, geralmente em matas de encostas e margens de estradas e trilhas, tanto em locais sombreados quanto ensolarados.

Integra um grupo de espécies afins da seção Leandraria, juntamente com L. fragilis, L. glazioviana e L. melastomoides, distinto, principalmente, pelas inflorescências em glomérulos, com invólucros de brácteas e profilos vistosos e geralmente de coloração vinosa na frutificação, além das flores pentâmeras e/ou hexâmeras. Mas é facilmente reconhecida pelas folhas com base auriculada, geralmente amplexicaule, e pelas brácteas e profilos involucrais, persistentes e vinosos na frutificação.

Leandra attenuata e L. pectinata foram assinaladas ocorrer em Macaé de Cima (Glaziou 1908), porém estão sendo consideradas prováveis sinônimos de L. amplexicaulis, não se dispondo de todo o material-tipo para se efetivar a sinonimização.
Leandra aspera Cogn. in A. \& C. De Candolle, Mon. Phan. 7: 655. 1891.

Fig. 2a-f

Arbustos 0,5-0,7 m alt. (Cogniaux 1891), nitidamente pilosos; indumento dos ramos, folhas, inflorescências e hipanto estriguloso-adpresso. Folhas com pecíolo $0,3-1 \mathrm{~cm}$ compr.; lâmina 2-5,3 $\times 0,6-1,5 \mathrm{~cm}$, estreito-elíptica a -oblonga, base aguda a obtusa, não amplexicaule, margem ondulada, estriguloso-ciliolada, ápice agudo a obtuso, às vezes subarredondado; 3 nervuras acródromas 0,5-2 mm suprabasais. Tirsóides ou botrióides de glomérulos; 2 brácteas involucrais e profilos cedo caducos. Flores 5-meras; hipanto 2,5-3 mm compr.; zona do disco glabra; lacínias do cálice eretas, as externas 1-1,2 mm compr., subuladas, as internas $0,9-1 \mathrm{~mm}$ compr.; pétalas 3,6-4,2 mm compr., eretas, oblongo-triangulares, ápice atenuado-acuminado, glabras; estames desiguais em tamanho, filetes $3,5-5,5 \mathrm{~mm}$ compr., anteras 2,5-3 $\mathrm{mm}$ compr., atenuadas, extrorsamente curvas, poro terminal, conectivo prolongado, dorsalmente bilobado; ovário 1/2ínfero, setuloso; estilete 8-9 mm compr. Frutos maduros do vistos.

Material examinado: 8(22).I.1888, fl., A.F.M. Glaziou 16861 (P, holótipo; BR, K, P, R, isótipos).

Endêmica da região de Macaé de Cima, em Nova Friburgo, sendo uma espécie rara e representada apenas pela coleção-tipo.

Reconhecida principalmente pelo indumento estriguloso, folhas com base aguda a obtusa, não amplexicaule, e brácteas involucrais, cedo caducas. Por essa característica das brácteas aproxima-se de L. hirta var. hirta, mas esta se distingue pelo indumento hirtelo-setoso.

Cogniaux (1891) posicionou L. aspera próxima a L. microphylla, uma espécie endêmica do Paraná, com folhas até $3 \mathrm{~cm}$ de comprimento, nervuras acródromas basais e tricomas dendríticos em ambas as faces (Camargo et al. 2009), além de $L$. linearifolia, L. parvifolia e L. salicina, que são distintas pelo indumento setoso ou seríceo e brácteas e profilos não involucrais, persistentes (Baumgratz \& Souza 2009c; Camargo et al. 2009).

Leandra atroviridis Cogn. in A. \& C. De Candolle, Mon. Phan. 7: 644. 1891.

Fig. $2 g$

Plantas aparentemente glabras; indumento dos ramos, folhas, inflorescências e hipanto esparsamente diminuto-estriguloso. Folhas com pecíolo 1-2,4 cm compr.; lâmina 4,2-8×1,4-2,5 cm, membranácea, elíptica, às vezes oblonga, base 

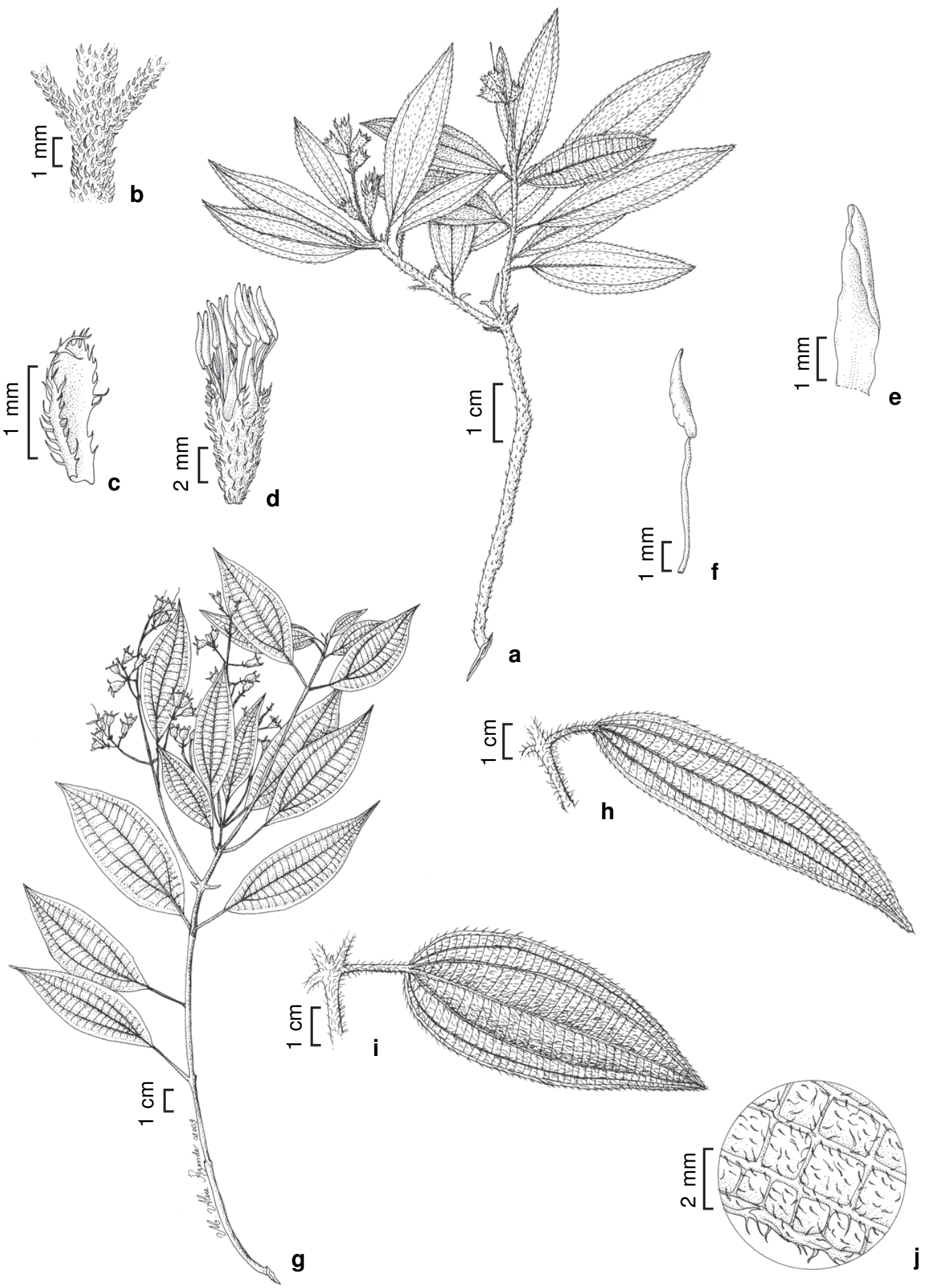

Figura 2 - a-f. Leandra aspera Cogn. - a. ramo florífero; b. detalhe do indumento no ramo; c. bráctea; d. flor; e. pétala; f. estame. g. Leandra atroviridis Cogn. - ramo florífero. h-j. Leandra aurea (Cham.) Cogn. - h-i. folhas, variação morfológica; j. detalhe do indumento da face abaxial da folha. (a-f Glaziou 16861; g Glaziou 16914; h-j Vieira \& Gurken 382). Figure 2 - a-f. Leandra aspera Cogn. - a. flowering branch; b. detail of the branch's indument; c. bract; d. flower; e. petal; f. stamen. g. Leandra atroviridis Cogn. - flowering branch. $\mathrm{h}-\mathrm{j}$. Leandra aurea (Cham.) Cogn. - h-i. leaves, morphological variation; j. detail of the foliar lamina indument on the abaxial surface. 
agudo-cuneada, margem inteira, ápice atenuadoacuminado; 5 nervuras acródromas 5-11 mm suprabasais. Tirsóides, 5-10 cm compr.; brácteas e profilos 1-1,5 mm compr., persistentes. Flores 5-meras; pedicelo 0,6-1,4 $\mathrm{mm}$ compr.; hipanto 2,7-3 $\mathrm{mm}$ compr.; lacínias do cálice patentes a reflexas, as externas 1,8-2,5 × 0,8-1 mm, oblongas, ápice arredondado, as internas $0,5-0,7 \mathrm{~mm}$ compr.; pétalas ca. $3 \mathrm{~mm}$ compr., estreitamente triangulares, ápice acuminado, glabras; estames e ovário não vistos; estilete 5-6,2 mm compr. Frutos maduros não vistos. Material examinado: 21.IV.1888, fr., A.F.M. Glaziou 16914 (BR, holótipo; BR, K, P, isótipos).

Endêmica da região de Macaé de Cima, em Nova Friburgo, sendo uma espécie rara e representada apenas pela coleção-tipo. Em virtude do escasso material, alguns dados vegetativos e florais foram obtidos e/ou complementados com base na descrição original (Cogniaux 1891).

Aproxima-se de L. acutiflora, L. laevigata e L. sphaerocarpa pelo aspecto aparentemente glabro da planta e folhas com nervuras acródromas suprabasais e destituídas de tricomas lepidoto-estrelados. Mas distingue-se principalmente pelas folhas com indumento diminuto-estriguloso (vs. furfuráceo-estrelado, glanduloso-pontoado e/ou setuloso) e lacínias externas do cálice 0,8-1 mm de largura ( $v s .0,1-0,5 \mathrm{~mm}$ ) e com ápice arredondado (vs. agudo ou agudo-apiculado). Cogniaux (1891) posicionou-a próximo a L. mollis e L. strigilliflora (Naudin) Cogn., porém, a presença evidente de indumento nos ramos dessas espécies, constituído de tricomas seríceosetulosos e hispídulos, respectivamente, as distinguem de L. atroviridis.

Leandra aurea (Cham.) Cogn. in Mart., Eichler \& Urban, Fl. bras. 14(4): 142. $1886 . \quad$ Fig. 2h-j

Arbustos ou arvoretas 2-3 m alt., nitidamente pilosos; indumento dos ramos, pecíolos, inflorescências, hipanto e lacínias externas do cálice esparsa a densamente furfuráceo-estrelado, tricomas caducos, e moderada a densamente hirtelo a hirsuto, tricomas glanduloso-granulosos ausentes; ramos subcilíndricos a cilíndricos, nunca alados. Folhas com pecíolo 0,7-2,4 cm compr.; lâmina 5,5-12 ×2-3,7 cm, membranácea a cartácea, lanceolada ou ovada, base arredondada a subcordada, não decorrente nem agudo-cuneada, margem crenado-ciliolada, ápice agudo ou atenuado, face adaxial plana a bulada, moderadamente setuloso- a setoso-adpressa, face abaxial foveolada ou não, moderada a densamente viloso-hirtela e furfuráceo-estrelada; 5 nervuras acródromas basais a 1-2 mm suprabasais. Tirsóides; brácteas e profilos persistentes. Flores 5-meras; hipanto 3,3-4,5 mm compr., também furfuráceo-dendrítico; zona do disco setulosa, anel membranáceo ausente; lacínias do cálice eretas, as externas 1,5-2,2 mm compr., as internas 0,2-0,3 mm compr.; pétalas 3,3-4 mm compr., reflexas, oblongo-elípticas ou elípticas, ápice agudo a atenuado, glabras; filetes 3-3,8 mm compr.; anteras 2,9-3,5 mm compr., róseas, ovadas, levemente curvas de forma extrorsa, conectivo não prolongado, giboso no dorso, inapendiculado ou apêndice agudo, truncado ou inconspícuobilobado; ovário 1/2-2/3-ínferos, 3-locular, setuloso; estilete 9,2-9,5 mm compr. Frutos maduros não vistos.

Material examinado: 18.VIII.1989, fl. e fr., I. Araujo et al. 67 (FLOR, RB, US); 19.VIII.1990, fl., J.F.A. Baumgratz et al. 476 (RB); 28.VIII.1993, fl. e fr., C.M. Vieira \& L.C. Gurken 382 (FLOR, RB); 15.XI.1993, fl. e fr., J.F.A. Baumgratz 496 (RB).

Distribui-se no Brasil, nos estados da Bahia, Minas Gerais, Rio de Janeiro, São Paulo, Paraná, Santa Catarina e, segundo Rambo (1966), no Rio Grande do Sul, além da Bolívia, tanto em formações vegetacionais de altitude quanto de planícies e vales. Este é o primeiro registro para a Reserva, sendo encontrada esporadicamente entre 1.100-1.400 m de altitude, na trilha para a Pedra Bicuda, Rio das Flores e estrada para a Fazenda Ouro Verde, em mata de encosta e nebular.

Leandra barbinervis (Cham. ex Triana) Cogn. in Mart., Eichler \& Urban, Fl. bras. 14(4): 159. 1886. Tipo: BRASIL: In Brasilia, fl., Sellow s.n. (holótipo $\mathrm{B}$, foto F!; isótipos K 000535614 !, P 00116832 !). Leandra trauninensis Cogn. in A. \& C. De Candolle, Mon. Phan. 7: 666. 1891. Tipo: BRASIL. RIO DE JANEIRO: 22.XII.1887, fl. e fr., A.F.M. Glaziou \& Traunin 16894 (lectótipo aqui designado, R!; isolectótipos K!, P-2x!), syn. nov. Leandra trauninensis var. major Cogn. in A. \& C. De Candolle, Mon. Phan. 7: 666. 1891. Tipo: BRASIL. RIO DE JANEIRO: 10.IX.1888, fl. e fr., A.F.M. Glaziou 17538 (lectótipo aqui designado, R!; isolectótipos $\mathrm{K}$ !, $\mathrm{P}-3 \mathrm{x}$ !), syn. nov.

Fig. 3a-b

Arvoretas 4-6 m alt., aparentemente glabras; indumento esparsa a moderadamente glandulosogranuloso, obscurecendo ou não tricomas furfuráceo-estrelados, estes geralmente caducos. Folhas com pecíolo 4,2-10,6 cm compr.; lâmina foliar 

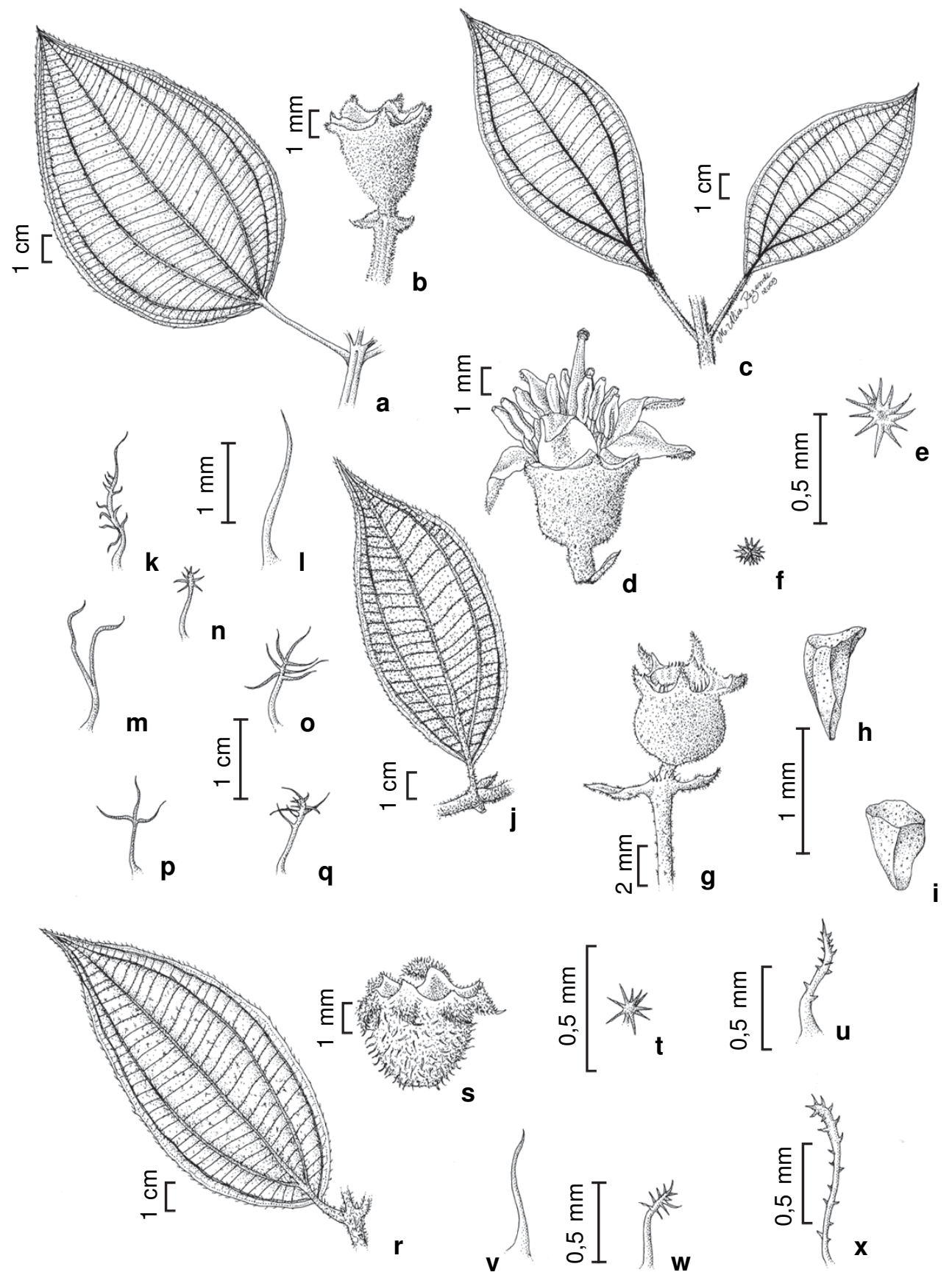

Figura 3 - a-b. Leandra barbinervis (Cham. ex Triana) Cogn. - a. folha; b. fruto jovem e profilos. c-i. Leandra breviflora Cogn. - c. folhas; d. flor e profilo; e-f. tricomas furfuráceo-estrelados; g. fruto jovem e profilos; h-i. sementes. j-q. Leandra carassana (DC.) Cogn. - j. folha; k-q. tipos de tricomas que compõem o indumento da planta (k, n-q. dendríticos; 1. setuloso; m. setuloso bífido). r-x. Leandra dasytricha (A.Gray) Cogn. - r. folha; s. fruto jovem; t-x. tipos de tricomas que compõem o indumento da espécie(t, w. dendríticos; $u$, x. setulosos ramificados; v. setuloso). (a-b Glaziou \& Traunin 16894; c-i Baumgratz et al. 548; j-q Baumgratz et al. 540; r-x Baumgratz et al. 532).

Figure 3 - a-b. Leandra barbinervis (Cham. ex Triana) Cogn. - a. leaf; b. young fruit and prophylls. c-i. Leandra breviflora Cogn. c. leaves; d. flower and prophyll; e-f. furfuraceous-stellate trichomes; g. young fruit and prophylls; h-i. seeds. j-q. Leandra carassana (DC.) Cogn. - j. leaf; k-q. trichomes of the plant indumenta (k, n-q. dendritic; l. setulose; m. bifid setulose). r-x. Leandra dasytricha (A.Gray) Cogn. - r. leaf; s. young fruit; $t-x$. trichomes of the plant indumenta (t, w. dendritic; $u, x$. branched setulose; v. setulose). 
(9-)12-23 × 5,5-14,5 cm, cartácea, largo-elíptica, base aguda ou obtuso-cuneada a arredondada, margem inconspícuo-denticulada, revoluta ou não, ápice arredondado-cuspidado a acuminado, face abaxial também geralmente setulosa nas nervuras acródromas; domácias marsupiformes, axilarprimárias; 5 nervuras acródromas $4-18 \mathrm{~mm}$ suprabasais, as laterais nitidamente afastadas das margens na porção basal. Tirsóides terminais, às vezes pseudo-axilares; brácteas e profilos geralmente persistentes, brácteas de primeira ordem tardiamente caducas. Flores 5-meras; hipanto 3,5$4 \mathrm{~mm}$ compr.; zona do disco setulosa; cálice distintamente laciniado, nunca truncado, lacínias eretas, as externas $0,7-1 \times$ ca. $0,5 \mathrm{~mm}$, gibosogeniculadas, ápice agudo, as internas $0,7-1,2 \mathrm{~mm}$ compr.; pétalas 4,2-4,5 $\mathrm{mm}$ compr., reflexas, elípticas, ápice atenuado, glabras; filetes 3-3,3 mm compr., anteras 2,5-2,7 mm compr., oblongas, levemente curvas de forma extrorsa, conectivo levemente giboso, prolongado ou não, com projeções ventrais bilobuladas; ovário 3/4-ínferos, 3-locular, glabro; estilete 10,2-10,5 mm compr. Frutos maduros não vistos.

Material examinado: 22.XI.1990, fl. e fr., J.F.A. Baumgratz et al. 510 (CEPEC, FLOR, K, MBM, RB, SPF).

Material adicional examinado: BRASIL. RIO DE JANEIRO: Teresópolis, Serra dos Órgãos, fl., 26.V.1869, A.F.M. Glaziou 3756 (P-2x); fl., J. Saldanha 6820 (RB); 26.IX.2007, fl., G. Heiden et al. 876 (RB). Itatiaia, 5.V.2009, fr., J.F.A. Baumgratz et al. 1120 (RB). Mun. indet., fl., VIII.1887, A.F.M. Glaziou 16962 (P).

Endêmica do Brasil, ocorrendo em Minas Gerais, Rio de Janeiro, São Paulo, Paraná e Santa Catarina. Na Reserva, cresce em mata de encosta, a ca. $1.400 \mathrm{~m}$ de altitude, sendo comum em locais sombreados e ensolarados.

Os diminutos tricomas estrelados podem ser frequentes ou de difícil visualização. Neste caso, por caírem muito cedo e serem esparsos, são geralmente obscurecidos pelos tricomas glandulosogranulosos. Na flora do estado de São Paulo, Souza \& Baumgratz (2009) também assinalam para essa espécie que os tricomas glanduloso-granulosos são muito mais numerosos e obscurecem os esparsos tricomas estrelados. A ausência de tricomas setulosos nas nervuras acródromas foliares foi observada apenas no exemplar Baumgratz 510.

Leandra trauninensis e L. trauninensis var. major foram descritas na seção Oxymeris (DC.) Cogn. (Cogniaux 1891) com base em espécimes coletados em Macaé de Cima (Glaziou 1908). Pelo aspecto vegetativo, principalmente a morfologia foliar, e características florais esses táxons são muito semelhantes. Apesar de haver, aparentemente, uma distinção entre estes táxons e $L$. barbinervis, baseada principalmente no tipo de indumento e na forma e dimensões da lâmina foliar e das lacínias do cálice (Cogniaux 1891), os exemplares-tipo mostram que correspondem a uma mesma espécie. Com base nas coleções examinadas e nos estudos de Souza \& Baumgratz (2009), observam-se variações e frequentes sobreposições das características descritas por Cogniaux (1886, 1891).

$\mathrm{Na}$ natureza, indivíduos jovens de $L$. barbinervis, com 2-2,5 $\mathrm{m}$ de altura, chegam a ter folhas com dimensões $60-80 \times 30-40 \mathrm{~cm}$, muito maiores do que aquelas citadas por Cogniaux (1886, 1891), e variando de largamente elípticas a suborbiculares. Estas formas também são encontradas em várias coleções (Baumgratz 510; Glaziou 16894, 17538; Sellow s.n.), assim como as nervuras acródromas podem ter ou não tricomas setulosos ao longo de seu comprimento ou estarem restritos à porção basal e os tricomas estrelados podem ser escassos ou muito obscurecidos pelos tricomas glandulosos. Desse modo, considera-se L. trauninensis e L. trauninensis var. major sinônimos de L. barbinervis.

Pelo aspecto aparentemente glabro da planta e morfologia das folhas, $L$. barbinervis pode assemelhar-se a $L$. quinquedentata e $L$. truncata. A primeira difere pela menor largura e número de nervuras acródromas na lâmina foliar, e a segunda, pelo cálice truncado-ondulado a -denticulado, com lacínias muito reduzidas.

Ao descrever L. trauninensis e L. trauninensis var. major Cogniaux (1891) não assinalou onde os exemplares-tipo estavam depositados. Desse modo, os espécimes Glaziou \& Traunin 16894 e Glaziou 17538, ambos do herbário R, são designados no presente estudo como lectótipos de L. trauninensis e L. trauninensis var. major, respectivamente, por estarem de acordo com as descrições dos protólogos e bem preservados.

Leandra breviflora Cogn. in Mart., Eichler \& Urban, Fl. bras. 14(4): 182, tab. 40, fig. 1. $1886 . \quad$ Fig. 3c-i Arvoretas ou árvores 2,5-9 m alt., nitidamente pilosas; indumento dos ramos, folhas, inflorescências, hipanto e cálice pardacento a ferrugíneo, esparsa a densamente furfuráceoestrelado, tricomas caducos ou não, tricomas glanduloso-granulosos ausentes; ramos achatados a subcilíndricos, nunca alados. Folhas com pecíolo 
3-8 cm compr.; lâmina $14-25 \times 5,5-10,5 \mathrm{~cm}$, cartácea, elíptica, às vezes obovada, base aguda a cuneada, não decorrente nem agudo-cuneada, margem crenulada, ápice cuspidado a acuminado, face adaxial brilhosa, glabrescente; 5 nervuras acródromas, 20-55 mm suprabasais. Tirsóides, terminais, às vezes também pseudo-axilares; brácteas e profilos persistentes. Flores 5-meras; hipanto 2,5-2,6 $\mathrm{mm}$ compr.; zona do disco setulosa, formando um anel membranáceo; lacínias do cálice eretas, as externas $0,6-0,7 \mathrm{~mm}$ compr., as internas 0,6-0,7 mm compr.; pétalas ca. $4 \mathrm{~mm}$ compr., reflexas, oblongo-triangulares, ápice agudo a atenuado, face adaxial glabra, face abaxial esparsa a moderadamente furfuráceo-estrelada ao longo da região mediana; filetes ca. 2,2 mm compr.; anteras 2,2-3 mm compr., alvas, obovado-cuneadas, truncadas, conectivo prolongado, inapendiculado; ovário 1/2-ínfero, 4locular, glabro ou esparso-setuloso; estilete ca. $6 \mathrm{~mm}$ compr. Bacídios 5-6 mm compr.

Material examinado: 21.I.1874, fl. e fr., A.F.M. Glaziou 6882 (P, R, síntipos); fl. e fr., A.F.M. Glaziou 13853 (P2x, síntipos); 22.I(III).1882, fl. e fr., A.F.M. Glaziou 13857 (P-3x, RB, síntipos); 27.IV.1988, fr., G. Martinelli et al. 12487, 12492 (CEPEC, FLOR, RB); 3.V.1988, fr., J.F.A. Baumgratz et al. 403 (FLOR, RB); 5.V.1988, fr., S.V.A. Pessoa et al. 330 (RB); 5-9.V.1988, fr., G. Martinelli et al. 12778 (RB); 9-12.V.1988, fr., G. Marinelli et al. 12779, 12780, 12783, 12807 (RB); 9-12.V.1988, G. Martinelli et al. 12940 (RB); 25.V.1988, fr., S.V.A. Pessoa et al. 329 (RB); 25.V.1988, fr., S.V.A. Pessoa et al. 328 (RB); 25.V.1988, fr., S.V.A. Pessoa et al. 331, 336 (FLOR, RB); 11.X.1988, fl., S.V.A. Pessoa et al. (RB 482486); 21.XI.1988, fl., S.V.A. Pessoa et al. 403 (RB); 22.XI.1988, fl., M. Nadruz et al. 422, 423 (RB); 6-10.III.1988, fr., $M$. Peron et al. 768 (FLOR, RB); 6-10.III.1988, fl. e fr., $M$. Peron et al. 778 (FLOR, RB, US); 17-21.VII.1989, fr., $M$. Peron et al. 793 (FLOR, RB); 12.IX.1989, fr., A. Fonseca Vaz et al.657 (RB); 7-16.V.1990, R. Guedes et al. (RB 294051); 17.VIII.1990, fr., J.F.A. Baumgratz et al. 463 (FLOR, RB); 22.XI.1990, fl., J.F.A. Baumgratz et al. 512 (FLOR, RB); 1990, fr., J.F.A. Baumgratz et al. (FLOR, RB); 16.I.1991, fl. e fr., J.F.A. Baumgratz et al. 534 (RB); 17.I.1991, fl. e fr., J.F.A. Baumgratz et al. 548 (CEPEC, FLOR, MBM, RB, SPF); 20.XII.1994, fl. e fr., M.L. Souza \& J.F. A. Baumgratz 1518 (FLOR, RB); 1.V.2001, fr., R.A.M. Tavares et al. 78 (CEPEC, FLOR, RB, MBM); 2.V.2001, fr., R.A.M. Tavares et al. 92 (RB); fl., R. Guedes et al. (RB 294040); R. Guedes et al. (RB 294043, RB 294049, RB 294050); H.C. Lima et al. (RB 294044).

Endêmica do Rio de Janeiro, ocorrendo na região de Macaé de Cima e na Serra dos Órgãos, no município de Teresópolis. Na Reserva, é muito comum, sendo encontrada em áreas no entorno dos Sítios Bacchus e Sophronites, Rio das Flores, Rio Macaé e ribeirão Santo Antonio, frequentemente entre 1.000-1.400 m de altitude, em mata de encosta e margem de rios, em locais sombreados e ensolarados.

Apesar de Cogniaux (1886) ter descrito o ovário como 3-locular, não se encontrou essa característica nos numerosos espécimes analisados.

Leandra carassana (DC.) Cogn. in Mart., Eichler \& Urban, Fl. bras. 14(4): 120. $1886 . \quad$ Fig. 3j-q

Arbustos a arvoretas 2-4 m alt., nitidamente pilosos; indumento dos ramos, pecíolos, face abaxial da lâmina foliar, inflorescências e hipanto constituído esparsa a densamente de tricomas dendríticos longo-pedicelados, com ramificações longas e adensadas no ápice, e tricomas setulosos, estes às vezes bífidos ou ausentes, tricomas glanduloso-granulosos ausentes; ramos achatados a subcilíndricos, nunca alados. Folhas com pecíolos 1,4-5,5 cm compr.; lâmina 10,2-20,5 ×4-8,7 cm, rígido-membranácea a cartácea, ovada a elíptica, base aguda a arredondada, margem crenuladociliolada, ápice atenuado-acuminado, face adaxial moderada a densamente setuloso-adpressa; 5-7 nervuras acródromas 11-30 mm suprabasais. Tirsóides de glomérulos; brácteas e profilos persistentes. Flores 5-meras; hipanto ca. 4,2 mm compr.; zona do disco esparso-setulosa; lacínias do cálice eretas, as externas 1,2-2,1 mm compr., as internas $0,3-0,5 \mathrm{~mm}$ compr.; pétalas $3-3,2 \mathrm{~mm}$ compr., reflexas, ovadas a oblongas, ápice agudo, glabras; filetes 3,8-5,5 mm compr.; anteras 4-4,7 $\mathrm{mm}$ compr., róseas, curvas, oblongo-lanceoladas, conectivo prolongado ou não, inapendiculado ou apêndice inconspícuo, agudo; ovário 1/3-1/4ínfero, 3-locular, setuloso; estilete 8,4-8,6 mm compr. Bacídios 5-7 mm compr.

Material examinado: 30.X.1887, fr., A.F.M. Glaziou 16832 (P); 8.I.1888, fl., A.F.M. Glaziou 16829 (K, P, R2x, RB); 22.I.1888, fr., A.F.M. Glaziou 16831 (P, R-2x); 11-14.X.1988, S.V.A. Pessoa et al. (RB 293886); 17.I.1991, fl. e fr., J.F.A. Baumgratz et al. 540 (FLOR, RB); 21.III.2007, fr., J.F.A. Baumgratz et al. 966 (FLOR, RB); fl. e fr., R. Guedes et al. 2118 (FLOR, RB); fr., S.V.A. Pessoa et al. (RB 293889).

Ocorre no Brasil, em Minas Gerais, Rio de Janeiro, São Paulo, Paraná, Santa Catarina e Rio Grande do Sul e, segundo Cogniaux (1891), também na Bolívia. Na Reserva, é encontrada em mata de encosta, ao longo da estrada para o Hotel Fazenda São João e Sítio Sophronites, entre 800-1.100 m de altitude, em locais sombreados na mata de encosta ao longo de trilhas e estradas. 
Afim de L. dasytricha e L. tetragona, principalmente pela semelhança morfológica das folhas e presença de tricomas dendríticos. A primeira se diferencia por estes serem sésseis ou curtopedicelados, com ramificações curtas ao longo do eixo principal, e pelas nervuras acródromas foliares curtamente (3-6 mm) suprabasais. Já a segunda é reconhecida pelos ramos tetragonais e subalados.

A ocorrência de L. sublanata em Macaé de Cima está baseada em Glaziou (1908) e nas coleções Glaziou 16831 e 16832 (P). Porém, recentemente, Souza \& Baumgratz (2004) a sinonimizaram com L. carassana.

O espécime Glaziou 16829, coletado na área de estudo e identificado por Cogniaux (1891) como L. confusa Cogn., pelas semelhanças morfológicas, corresponde a L. carassana e, provavelmente, tratam-se de um único táxon.

Leandra dasytricha (A.Gray) Cogn. in Mart., Eichler \& Urban, Fl. bras. 14(4): 113. 1886.

Fig. 3r-x.

Arvoretas 2,5-4 $\mathrm{m}$ alt., nitidamente pilosas; indumento dos ramos, pecíolos, nervuras na face abaxial da lâmina foliar, inflorescências e hipanto moderada a densamente constituído de tricomas dendríticos, sésseis ou curto-pedicelados, com ramificações curtas ao longo do eixo principal, e tricomas setulosos, estes rugosos, tricomas glanduloso-granulosos ausentes; ramos achatados a cilíndricos, nunca alados. Folhas com pecíolo 0,6 2,8 cm compr.; lâmina 8,6-25 × 3,7-10,7 cm, membranácea, elíptica, base obtusa a arredondada, margem crenulado-ciliolada, ápice agudo a atenuado-acuminado, face adaxial estrigulososetulosa, face abaxial também com tricomas setulosos; 5 nervuras acródromas 3-6 mm suprabasais. Tirsóides de glomérulos ou não; brácteas e profilos persistentes. Flores 5-meras; hipanto 2,5-2,6 mm compr.; zona do disco setulosa; lacínias do cálice reflexas, as externas 0,6-1 mm compr., as internas $0,3-0,5 \mathrm{~mm}$ compr.; pétalas ca. 2,8 mm compr., reflexas, estreito-lanceoladas, ápice agudo e dorsalmente esparso-pubescente, tricomas caducos; filetes ca. 1,4 mm compr.; anteras ca. 1,5 mm compr., alvas, ovadas, conectivo não prolongado, inapendiculado; ovário 3/4-ínferos, 3locular, esparso-setuloso; estilete 5-5,2mm compr. Frutos maduros não vistos.

Material examinado: 2.VIII.1887, fr., A.F.M. Glaziou 16869 (P); 20.XII.1887(22.I.1888), fl., A.F.M. Glaziou 16870 (P); 7.VI.1989, fr., J.F.A. Baumgratz et al. 438
(FLOR, RB, US); 17-21.VII.1989, fr., M. Peron et al. 805 (FLOR, RB, US); 9.VIII.1990, C.M.B. Correia et al. (RB 294034); 11.IX.1990, fr., C.M.B. Correia et al. 153A (RB); 16.I.1991, fl. e fr., J.F.A. Baumgratz et al. 532 (RB); 20.XII.1994, fl. e fr., M.L. Souza \& J.F.A. Baumgratz 1489 b (FLOR, RB).

Endêmica do Brasil, ocorrendo no Espírito Santo, Rio de Janeiro, São Paulo, Paraná, Santa Catarina e Rio Grande do Sul. Este é o primeiro registro para a Reserva, sendo encontrada em mata de encosta, ao longo da estrada para o Hotel Fazenda São João e Sítio Sophronites, entre 900-1.200 m de altitude, em matas de encosta e ao longo de trilhas e estradas, em locais sombreados e ensolarados.

Afim de L. carassana, conforme comentado nesta espécie, e de L. tetragona, que se distingue pelos ramos tetragonais e subalados. Na flora de São Paulo, Souza \& Baumgratz (2009) não observaram tricomas nas pétalas de L. dasytricha.

Leandra eriocalyx Cogn. in A. \& C. De Candolle, Mon. Phan. 7: 642. 1891.

Fig. 4a-e

Arvoretas 3-5 m alt., nitidamente pilosas; indumento dos ramos, pecíolos e inflorescências esparsa a densamente hirtelo e esparsamente furfuráceo-estrelado, tricomas glandulosogranulosos ausentes; ramos subcilíndricos a cilíndricos, nunca alados. Folhas com pecíolo 0,5$0,7 \mathrm{~cm}$; lâmina 8-10×2-2,9 cm, papirácea, lanceolada ou elíptica, base aguda ou obtusa, não decorrente nem agudo-cuneada, margem crenulado-ciliolada, ápice acuminado, face adaxial moderadamente estrigulosa, sobre a nervura acródroma central setulosa, face abaxial moderadamente setosa e setoso-vilosa e esparsamente furfuráceo-estrelada; 5 nervuras acródromas 4-5 mm suprabasais. Tirsóides; brácteas e profilos persistentes. Flores (4-)5-meras; hipanto ca. $3 \mathrm{~mm}$ compr., hirtelo; zona do disco setulosa; lacínias do cálice reflexas, as externas 1,3-1,8 mm compr., as internas 0,5-0,7 mm compr.; pétalas 2,6-2,7 mm compr., reflexas, elípticas a triangulares, ápice agudo-acuminado, glabras, margem às vezes esparsamente ciliolado-setulosa na base; filetes 1,9-2,3 mm compr., anteras 1,8-2,2 mm compr., alvas, oblongas, conectivo não prolongado, inapendiculado; ovário 2/3-3/4-ínferos, 3-locular, setuloso; estilete 6-6,7 mm compr. Frutos maduros não vistos.

Material examinado: 8.I.1888, fr., A.F.M. Glaziou 16854 (BR, P, isolectótipos, R, lectótipo); 8.I.1888, fl., A.F.M. Glaziou 16858 a (BR, P, R, parátipos); 20.XII.1994, fl. e fr., M.L. Souza \& J.F.A Baumgratz 1501 (FLOR, RB). 

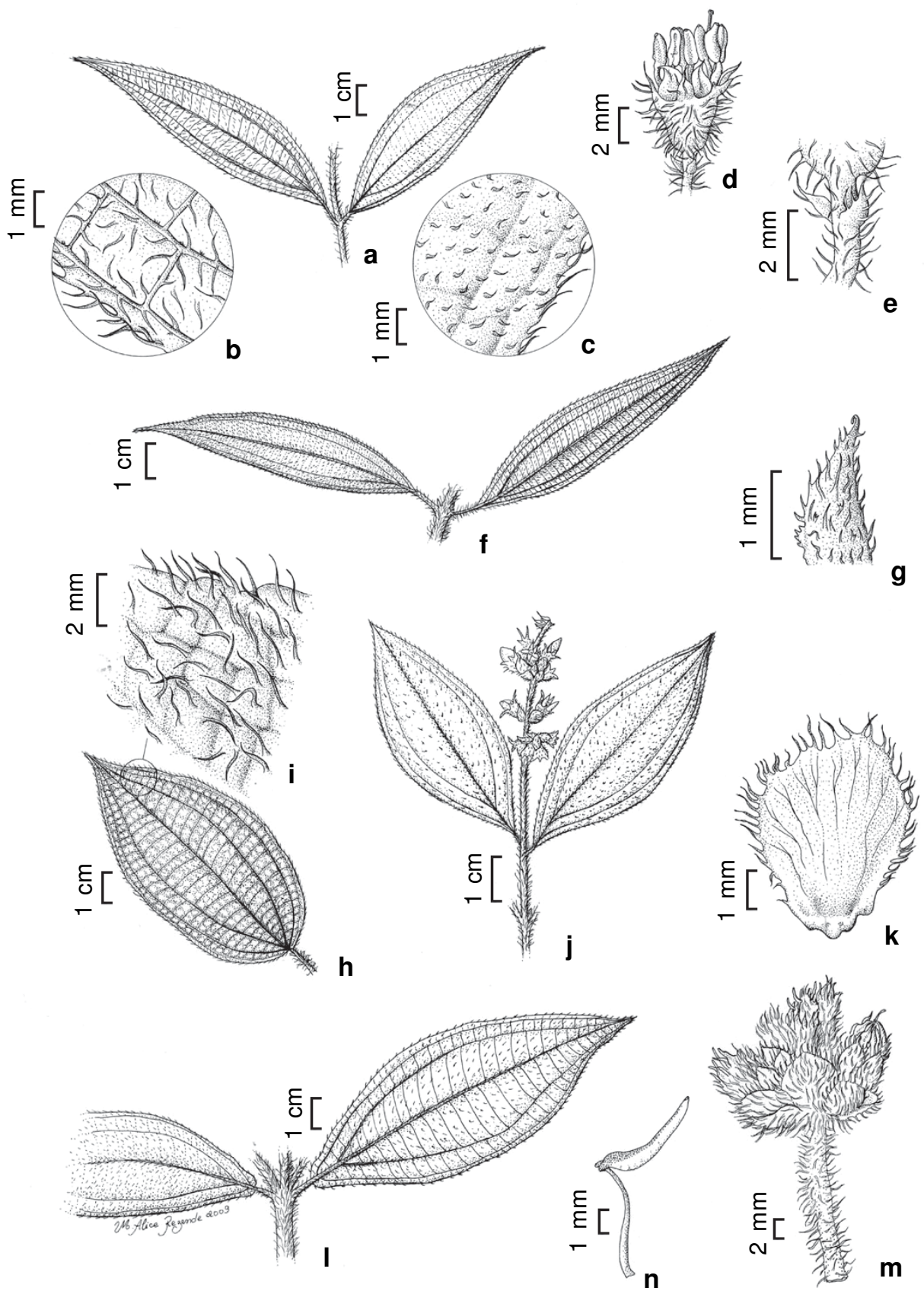

Figura 4 - a-e. Leandra eriocalyx Cogn. - a. folhas; b-c. detalhes do indumento das faces abaxial e adaxial da folha, respectivamente; d. flor; e. inserção dos profilos. f-g. Leandra fallax (Cham.) Cogn. -f. folhas; g. pétala, face abaxial furfuráceoestrelada e curto-setulosa. h-i. Leandra foveolata (DC.) Cogn. - h. folha; i. detalhe do indumento da face adaxial da folha. $\mathrm{j}$-k. Leandra fragilis Cogn. - j. detalhe do ramo florífero; k. bráctea, face abaxial. 1-n. Leandra glazioviana Cogn. - 1. folhas; $\mathrm{m}$. detalhe do ramo da inflorescência, evidenciando as brácteas involucrais e pilosas na face abaxial; n. estame. (a-e Souza \& Baumgratz 1501; f-g Souza \& Baumgratz 1493; h-i Souza \& Baumgratz 1497; j-k Baumgratz et al. 538; 1-n Baumgratz et al. 526) Figure 4 - a-e. Leandra eriocalyx Cogn. - a. leaves; b-c. details of leaf indument on the abaxial and adaxial surface, respectively; $d$. flower; e. insertion of the prophylls. f-g. Leandra fallax (Cham.) Cogn. - f. leaves; g. petal, abaxial surface stellate-furfuraceous and shortsetulose. h-i. Leandra foveolata (DC.) Cogn. - h. leaf; i. detail of the adaxial surface foliar indument. j-k. Leandra fragilis Cogn. - j. detail of the flowering branch; k. bract, abaxial surface. 1-n. Leandra glazioviana Cogn. - 1. leaves; m. detail of the inflorescence branch, showing the bracted-capitate cluster and the bracts pilose on the abaxial surface; $n$. stamen. 
Endêmica da região de Macaé de Cima, em Nova Friburgo, sendo rara e recoletada somente 106 anos após a coleta do tipo. Na Reserva, ocorre em mata de encosta ao longo da estrada para o Sítio Sophronites, ca. $1.100 \mathrm{~m}$ de altitude, em locais sombreados da mata de encosta.

Espécie próxima à L. fallax e L. purpurascens, porém difere da primeira pelas pétalas glabras e da segunda pelos menores comprimentos das lacínias externas do cálice (1,3-1,8 mm vs. 2,8-3 mm), pétalas (2,6-2,7 mm vs. ca. 3,5 mm) e estilete (6-6,7 $\mathrm{mm} v s$. ca. 7,3 mm) e pelas anteras alvas ( $v s$. amarelas). Por semelhanças morfológicas foliares pode ser confundida no campo também com L. laxa, mas esta se diferencia pela face adaxial esparso-setulosa e menor comprimento dos lobos externos do cálice $(0,5-1 \mathrm{~mm})$.

Leandra fallax (Cham.) Cogn. in Mart., Eichler \& Urban, Fl. bras. 14(4): 123. $1886 . \quad$ Fig. 4f-g

Arbustos 1-1,7 m alt., nitidamente pilosos; indumento dos ramos, pecíolos, inflorescências e hipanto esparsa a densamente hirtelo e furfuráceoestrelado, tricomas glanduloso-granulosos ausentes; ramos subcilíndricos a cilíndricos, nunca alados. Folhas com pecíolo 0,6-1,5 cm compr.; lâmina 5,6-15 $\times 1,9-3,9 \mathrm{~cm}$, cartácea, estreito-elíptica a lanceolada, base aguda, não decorrente nem agudo-cuneada, margem crenulado-ciliolada, ápice agudo a atenuadoacuminado, face adaxial bulada, denso-estrigulosa, face abaxial foveolada, denso-vilosa, furfuráceoestrelada e hirtela nas nervuras acródromas; 5 nervuras acródromas 4-18 mm suprabasais. Tirsóides; brácteas e profilos persistentes. Flores 5meras; hipanto 3-3,5 mm compr., denso-hirsuto e furfuráceo-estrelado; zona do disco setulosa; lacínias do cálice reflexas, as externas 1-1,5 mm compr., as internas $0,4-0,6 \mathrm{~mm}$ compr., praticamente unidas às internas; pétalas 1,8-2,3 mm compr., reflexas, ovadas a elípticas, ápice atenuadoapiculado, face adaxial glabra ou levemente pubérula, face abaxial furfuráceo-estrelada e curto-setulosa; filetes 1,5-2 mm compr.; anteras 1,7-2,3 mm compr., alvo-rosadas, oblongas, conectivo não prolongado, inapendiculado; ovário 1/3-1/2-ínfero, 3-locular, setuloso; estilete 5,2-5,3 mm compr. Frutos maduros não vistos.

Material examinado: 20.XII.1994, fl., M.L. Souza \& J.F.A. Baumgratz 1493, 1504 (FLOR, RB).

Endêmica do Brasil, ocorrendo em Minas Gerais, Espírito Santo, Rio de Janeiro, São Paulo, Paraná e Santa Catarina. Não é comum na Reserva, sendo esse o primeiro registro; encontrada em mata de encosta na estrada para o Sítio Sophronites, em torno de $1.100 \mathrm{~m}$ de altitude, em locais sombreados em mata de encosta.

Espécie próxima de L. eriocalyx, conforme abordado nos comentários dessa espécie. Também tem afinidade com L. purpurascens, mas esta se diferencia principalmente pelas folhas com a face adaxial plana, lacínias externas do cálice maiores em comprimento $(2,8-3 \mathrm{~mm})$ e pétalas glabras e maiores em comprimento (ca. 3,5 mm).

Leandra foveolata (DC.) Cogn. in Mart., Eichler \& Urban, Fl. bras. 14(4): 100. $1886 . \quad$ Fig. 4h-i

Arvoretas 1,5-2 $\mathrm{m}$ alt., nitidamente pilosas; indumento dos ramos, pecíolos e inflorescências hirsuto e esparsamente furfuráceo-estrelado, tricomas glanduloso-granulosos ausentes; ramos subcilíndricos a cilíndricos, nunca alados. Folhas com pecíolo 1,4-3,4 cm compr.; lâmina 8,7-13,4 $\times$ 3,8-4,8 cm, cartácea, estreito-ovada, às vezes oblonga, base arredondada a subcordada, não decorrente nem agudo-cuneada, margem crenulado-ciliolada, ápice agudo a acuminado, moderada a densamente setuloso-setosa e esparsamente furfuráceo-estrelada, face adaxial bulada, brilhosa, tricomas 1,5-2,7 mm compr., face abaxial foveolada; 5 nervuras acródromas basais a 1-2 mm suprabasais. Tirsóides; brácteas e profilos persistentes. Flores 5-meras; hipanto ca. 4,5 mm compr., esparsa a moderadamente setuloso e moderada a densamente furfuráceo-estrelado; zona do disco glabra ou setulosa, anel membranáceo ausente; lacínias do cálice reflexas, as externas 2,3$3,3 \mathrm{~mm}$ compr., as internas $0,4-0,5 \mathrm{~mm}$ compr.; pétalas 4,2-4,3 mm compr., reflexas, elípticas ou ovadas, ápice atenuado-apiculado, glabras; filetes ca. 3,5 mm compr.; anteras 3,3-3,5 mm compr., róseas, lanceoladas, extrorsamente falciformes, conectivo dorsalmente giboso, prolongado ou não, inapendiculado ou apêndice truncado; ovário 1/2ínfero, 3-locular, setuloso; estilete 9,2-9,5 mm compr. Frutos maduros não vistos.

Material examinado: 19.VIII.1990, fl., J.F.A. Baumgratz et al. 477 (FLOR, RB); 20.XII.1994, fl. e fr., M.L. Souza \& J.F.A. Baumgratz 1497 (FLOR, RB).

Material adicional examinado: BRASIL. RIO DE JANEIRO: Araras, 2.VI.1984, fl. e fr., J.F.A. Baumgratz 290 \& R. Guedes 832 (CEPEC, FLOR, RB).

Distribui-se no Brasil, em Minas Gerais, Rio de Janeiro e São Paulo e, segundo Cogniaux (1886, 1891), também na Guyana, geralmente em matas de altitude. Espécie não muito comum na Reserva, sendo 
esse o primeiro registro; encontrada em área do Sítio Sophronites e no caminho para a Pedra Bicuda, entre 1.100-1.400 m de altitude, em mata nebular e bordas de matas de encosta ao longo de estradas.

Pelo aspecto da pilosidade dos ramos, folhas e inflorescências assemelha-se a L. xanthostachya e L. nianga, mas as folhas não buladas nem foveoladas distinguem-nas de L. foveolata.

Leandra fragilis Cogn. in Mart., Eichler \& Urban, Fl. bras. 14(4): 88, tab. 18, fig. 2. $1886 . \quad$ Fig. 4j-k

Subarbustos a arbustos 0,8-2,5 m alt., nitidamente pilosos; indumento dos ramos, pecíolos e inflorescências hispídulo-estriguloso. Folhas com pecíolo 0,2-0,9 cm compr.; lâmina 5,7-14,1 ×2-3,8 $\mathrm{cm}$, papirácea ou cartácea, elíptica, base aguda a cuneada, às vezes arredondado-decorrente, não amplexicaule, margem crenulado-ciliolada, ápice agudo-acuminado a atenuado, face adaxial estrigulosa, hispídula nas nervuras acródromas, face abaxial setulosa a hispídula, estrigulosa nas nervuras acródromas; 3(-5) nervuras acródromas 5-15 mm suprabasais. Tirsóides de glomérulos; brácteas e profilos involucrais, persistentes na frutificação, brácteas mais externas dos invólucros florais com a face abaxial glabra ou tricomas restritos à região da nervura central. Flores (5-)6meras; hipanto ca. 4 mm compr.; zona do disco glabra; lacínias do cálice eretas, as externas ca. $1,5 \mathrm{~mm}$ compr., as internas ca. $2 \mathrm{~mm}$ compr.; pétalas 4,5-5 mm compr., eretas, estreito-elípticas, ápice atenuado, apiculado ou não, glabras; estames de dois tamanhos, ante-sépalos com filetes 4,5-6 mm compr., anteras ca. $4 \mathrm{~mm}$ compr., antepétalos com filetes ca. $4 \mathrm{~mm}$ compr., anteras 3,5-4,1 mm compr., ambos com anteras róseas, ovadas, extrorsamente falciformes, conectivo prolongado, apêndice truncado ou agudo; ovário 1/6-1/3-ínfero, 4locular, setuloso; estilete 6,5-10,1 mm compr. Bacídios ca. $7 \times 3 \mathrm{~mm}$.

Material examinado: 18.VI.1986, fr., G. Martinelli et al. 11716 (RB); 17.I.1991, fl., J.F.A. Baumgratz et al. 538 (RB); V.2001, fr. e fr., R.A.M. Tavares et al. 87, 97 (RB). Material adicional examinado: BRASIL. RIO DE JANEIRO: Santa Maria Madalena, 4.III.1935, fl., A.C. Brade \& Santos Lima 14235 (RB).

Endêmica do Brasil, ocorrendo na Bahia, Espírito Santo, Rio de Janeiro, São Paulo, Paraná e Santa Catarina. Primeiro registro para a Reserva, tendo sido coletada no entorno da Pedra Bicuda e da nascente do Rio das Flores, entre 900-1.000 m de altitude, em locais sombreados que margeiam estradas ou trilhas no interior da mata de encosta.
Afim de L. amplexicaulis, L. glazioviana e L. melastomoides, conforme abordado nos comentários da primeira espécie. Dentre estas, aproxima-se mais de L. melastomoides, que difere, principalmente, pelas brácteas mais externas do invólucro com a face abaxial pilosa, às vezes exceto nos bordos.

Leandra glazioviana Cogn. in Mart., Eichler \& Urban, Fl. bras. 14(4): 86, tab. 18, fig. 1. 1886.

Fig. 41-n

Arbustos a arvoretas, 1,2-3 m alt., nitidamente pilosos; indumento dos ramos, pecíolos e inflorescências hispídulo-estrigulosos, tricomas iguais ou maiores que $2 \mathrm{~mm}$ compr., patentes a reflexos, nunca adpressos. Folhas com pecíolo $0,3-$ 0,8 cm compr.; lâmina 5,6-20 × 2,2-7,3 cm, papirácea, elíptica, base obtusa- a arredondadocuneada, não amplexicaule, margem denticuladociliolada, ápice agudo-acuminado, face adaxial bulada, estrigulosa, face abaxial plana a foveolada, setosa, hispídula nas nervuras; 3 nervuras acródromas 6-25 mm suprabasais. Tirsóides de glomérulos; brácteas e profilos involucrais, persistentes na frutificação, brácteas mais externas dos invólucros florais com indumento revestindo totalmente a superfície da face abaxial. Flores 6meras; hipanto 4,8-6 mm compr.; zona do disco glabra; lacínias do cálice eretas, as externas 1,8-2,2 mm compr., as internas 1,5-3 mm compr.; pétalas 4-6 mm compr., eretas, oblongas, ápice atenuado, dorsalmente apiculado, glabras; estames desiguais em tamanho, filetes 5,6-7 mm compr.; anteras 4,7$6,2 \mathrm{~mm}$ compr., róseas, conectivo prolongado ou não, apendiculado; ovário 1/2-4/5-ínferos, 4locular, piloso; estilete 7,5-14 mm compr., glabro ou esparso-estriguloso para a base. Frutos maduros não vistos.

Material examinado: 22.I.1888, fl., A.F.M. Glaziou 16824 (BR, K, P, R, RB); 16.I.1991, fl. e fr., J.F.A. Baumgratz et al. 526 (RB); 16.I.1991, fl., J.F.A. Baumgratz et al. 533 (RB); 6.VI.1993, fr., C.M. Vieira et L.C. Gurken 259 (RB); 2.V.2001, fr., R.A.M. Tavares et al. 91 (FLOR, RB).

Material adicional examinado: BRASIL. RIO DE JANEIRO: Teresópolis, Serra dos Órgãos, 30.I.1875, fl., A.F.M. Glaziou 7616 (P, holótipo; K, P, R, isótipos). Apiahy, IV.1886, fl., A.F.M. Glaziou 16002b (P).

Endêmica do Brasil, ocorrendo no Rio de Janeiro, São Paulo, Paraná e Santa Catarina. Primeiro registro para a Reserva, tendo sido coletada em área próxima ao Hotel Fazenda São João e em direção ao Rio Macaé, na Fazenda Ouro Verde, entre 
900-920 m de altitude, em bordas de matas de encosta ao longo de estradas e em trilhas próximas a rios, em locais sombreados.

Espécie muito semelhante vegetativamente e, por características florais, a $L$. amplexicaulis, $L$. fragilis e L. melastomoides, conforme abordado nos comentários das duas primeiras espécies. Entretanto, distingui-se, principalmente, pelas maiores dimensões das peças florais, conforme já destacado por Souza \& Baumgratz (2004). Neste trabalho, os autores também propuseram L. melastomoides Raddi var. paulina Cogn. e L. pubistyla Wurdack como sinônimos de L. glazioviana.

Leandra gracilis Cogn. in Mart., Eichler \& Urban, Fl. bras. 14(4): 163, tab. 36, fig. 1. $1886 . \quad$ Fig. 5a

Arbustos ou arvoretas 1-2,5 m alt., nitidamente pilosos; indumento dos ramos, folhas, inflorescências e hipanto esparsa a densamente glanduloso-granuloso, obscurecendo tricomas furfuráceo-estrelados, tricomas caducos ou não; ramos também esparso-setuloso, às vezes restrito aos nós. Folhas com pecíolo 1,6$2 \mathrm{~cm}$ compr.; lâmina $5,5-14 \times 1,2-5 \mathrm{~cm}$, membranácea, elíptica a estreito ovada, base cuneada, às vezes curto-decorrente ou obtusocuneada, margem crenulado-ciliolada, ápice atenuado-acuminado, às vezes acuminado ou falcado, face abaxial setulosa nas nervuras acródromas; 5 nervuras acródromas $6-16 \mathrm{~mm}$ suprabasais. Tirsóides, ramos acessórios presentes; brácteas e profilos persistentes. Flores 5-meras; hipanto 2,8-3,2 mm compr., também esparso-setuloso; zona do disco esparsa e irregularmente denticulada, glabra; lacínias do cálice eretas, as externas $0,3-0,6 \mathrm{~mm}$ compr., as internas $0,1-0,3 \mathrm{~mm}$ compr.; pétalas $2-2,5 \mathrm{~mm}$ compr., reflexas, elípticas a ovadas ou lanceoladas, ápice atenuado, glabras; filetes 1,5-1,6 mm compr.; anteras 1,7-1,8 mm compr., elíptico- ou oblongocuneadas, conectivo prolongado, inapendiculado; ovário 3/4-2/3-ínferos, 3-locular, glabro; estilete 6-7,3 mm compr. Bacídios 4-7 mm compr.

Material examinado: 30.VIII.1887, fl., A.F.M. Glaziou 16920 (BR-2x, K, P); 8.II.1988, fl., S.V.A. Pessoa et al. 431 (FLOR, RB); 5-9.XII.1988, S.V.A. Pessoa et al. (RB 294030); 22.XI.1990, fl., J.F.A. Baumgratz et al. 508 (FLOR, RB); 22.XI.1990, fl., J.F.A. Baumgratz et al. 511 (FLOR, MBM, RB); 20.XII.1994, fr., M.L. Souza \& J.F.A. Baumgratz 1495b (CEPEC, FLOR, RB); 20.XII.1994, fl. e fr., M.L. Souza \& J.F.A. Baumgratz 1499 (FLOR, RB); 20.XII.1994, fl. e fr., M.L. Souza \& J.F.A. Baumgratz 1500 (CEPEC, FLOR, RB);
21.XII.1994, fl. e fr., M.L. Souza \& J.F.A. Baumgratz $1519 b$ (CEPEC, FLOR, K, MBM, RB, SPF).

Material adicional examinado: BRASIL. RIO DE JANEIRO: Teresópolis, Serra dos Órgãos, 18.I.1883, fl., J. Saldanha 6823 (R, isosíntipo); 18.IX.1887, fl. e fr., A.F.M. Glaziou 16901 (BR, K, P, R, isosíntipos). Mun. indet., fl., L. Riedel 1868 (BR, isosíntipo).

Endêmica do Brasil, restrita ao Rio de Janeiro e São Paulo. Na Reserva, é encontrada em áreas entorno do Rio das Flores e Sítio Sophronites, entre 900-1.400 $\mathrm{m}$ de altitude, em matas de encosta ao longo de estradas e trilhas, em locais sombreados e ensolarados.

Assemelha-se pela morfologia foliar a $L$. multisetosa, que se distingue pelo indumento do tipo hirtelo e revestindo totalmente a face abaxial da lâmina foliar e os ramos.

Leandra gracilis var. glazioviana Cogn., descrita por Cogniaux (1891) para Macaé de Cima, foi reconhecida como um novo táxon (ver comentários em L. altomacaensis).

Leandra hirta Raddi var. hirta, Mem. Mat. Fis. Soc. Ital. Sci. 18(2): 387. 1820. Tipo: fr., G. Raddi s.n. (holótipo FI; foto em RB!). Leandra hirta var. parvifolia Cogn. Tipo: BRASIL. RIO DE JANEIRO: Alto Macaé, 8.I.1888, fl., A.F.M. Glaziou 16859 (lectótipo aqui designado, RB!; isolectótipos BR!, K!, NY!, P-3x!, R-2x!), syn. nov. Fig. 5b-c

Arbustos 1,9-2,3 m alt., nitidamente pilosos; indumento dos ramos, folhas, inflorescências, hipanto e cálice esparsa a densamente hirtelosetoso, tricomas adpressos. Folhas com pecíolo 0,3-2 cm compr.; lâmina 3,4-11,8 × 1,2-3 cm, membranácea, elíptica, base obtusa a cuneada, não amplexicaule, margem crenulado-ciliolada, ápice agudo a acuminado; 3(-5) nervuras acródromas 4$6 \mathrm{~mm}$ suprabasais. Tirsóides de glomérulos; 2 brácteas involucrais e profilos cedo caducos. Flores 5-meras; hipanto 3-3,4 mm compr.; zona do disco glabra; lacínias do cálice eretas, as externas 0,9-1,5 mm compr., as internas $0,8-1,3 \mathrm{~mm}$ compr.; pétalas ca. 2,5 mm compr., eretas, oblongo-triangulares, ápice atenuado-acuminado, apiculado, glabras; filetes 2,5-3 mm compr.; anteras 2-3 mm compr., oblongas, conectivo não prolongado, inapendiculado ou apêndice inconspícuo; ovário 2/3-ínferos, 4locular, setoso; estilete 10-13 mm compr. Bacídios ca. $4,5 \mathrm{~mm}$ compr.

Material examinado: 22.I.1888, fl., A.F.M. Glaziou s.n. (P). Material adicional examinado: BRASIL. RIO DE JANEIRO: Rio de Janeiro, I.1933, fl. e fr., A.C. Brade et al. 12426 (RB). Mun. indet., 1831-33, fl., C. Gaudichaud 728 (P). 


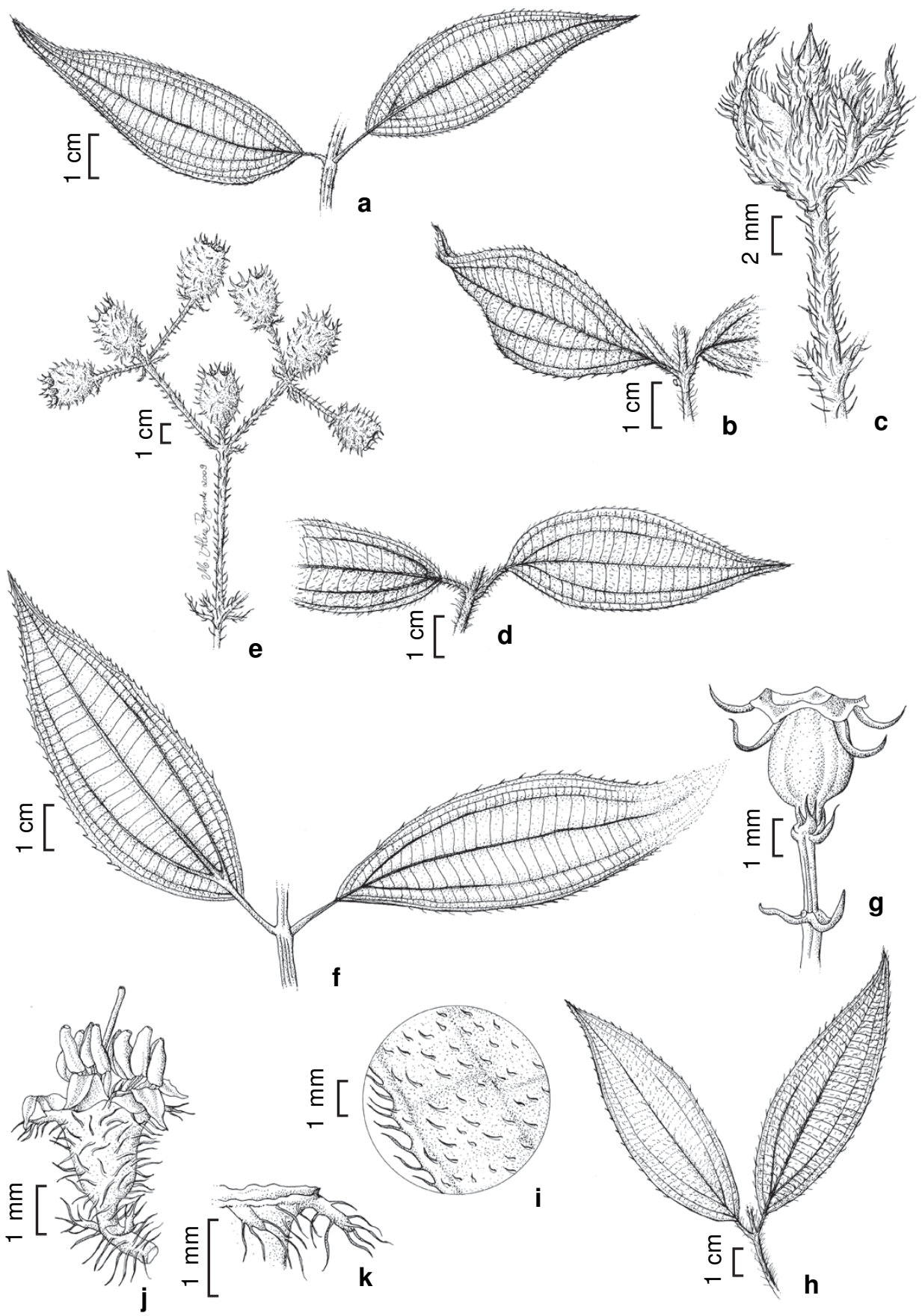

Figura 5 - a. Leandra gracilis Cogn. - folhas. b-c. Leandra hirta Raddi var. hirta - b. folhas; c. ramo da inflorescência, evidenciando as brácteas involucrais. d-e. Leandra hirtella Cogn. - d. folhas; e. detalhe do ramo da inflorescência com frutos jovens. f-g. Leandra laevigata (Triana) Cogn. - f. folhas; g. brácteas, profilos e fruto jovem. h-k. Leandra laxa Cogn. - h. folhas; i. detalhe do indumento na face adaxial da folha; j. flor; k. lacínia do cálice. (a Baumgratz et al. 511; b-c Glaziou 16859; d-e Baumgratz et al. 447; f-g Baumgratz et al. 482; h-k Baumgratz et al. 374)

Figure 5 - a. Leandra gracilis Cogn. - leaves. b-c. Leandra hirta Raddi var. hirta - b. leaves; c. inflorescence branchlet, showing the bracted-capitate cluster. d-e. Leandra hirtella Cogn. - d. leaves; e. detail of the inflorescence branch with young fruits. f-g. Leandra laevigata (Triana) Cogn. - f. leaves; g. bracts, prophylls, and young fruit. h-k. Leandra laxa Cogn. - h. leaves; i. detail of the foliar indument of adaxial surface; j. flower; k. calyx lobe. 
Endêmica do Rio de Janeiro. Na Reserva, é uma espécie rara e de onde só se dispõe de exemplares históricos para análise.

Apesar de pertencer à seção Leandraria, as duas brácteas involucrais, na base de cada glomérulo, são muito cedo caducas e não apresentam aspecto rosulado, uma característica das espécies dessa seção (Cogniaux 1886). Pelo hábito arbustivo, aspecto do indumento e folhas membranáceas, com nervuras acródromas suprabasais, aproxima-se de L. hirtella e L. mollis. Ambas se distinguem, principalmente, pela ausência de brácteas involucrais e cedo caducas, além de a primeira possuir indumento glandulosogranuloso e a segunda ter as nervuras acródromas mais suprabasais (6-18 $\mathrm{mm})$.

As características diagnósticas de L. hirta var. parvifolia, descritas por Cogniaux (1886, 1891) com base em um exemplar coletado na Reserva (Glaziou 16859), como o caule muito ramificado e as folhas com menores dimensões do pecíolo (5-8 mm compr.) e da lâmina foliar (4-6 × 1,5-2,5 cm), lanceoladas e curtamente acuminadas, não se mostram exclusivas para o reconhecimento desse táxon infraespecífico. Com base nos espécimes analisados, essas características se sobrepõem àquelas descritas para a variedade típica e um mesmo exemplar pode, às vezes, apresentar características de ambas as variedades. Desse modo, considera-se a variedade parvifolia sinônimo de L. hirta var. hirta. Como Cogniaux (1891) não indicou o herbário onde o exemplar-tipo da variedade parvifolia estaria depositado, designa-se no presente estudo o espécime Glaziou 16859 (R) como lectótipo desta variedade, por estar de acordo com a descrição do protólogo e bem preservado.

O espécime Glaziou s.n. (P), coletado na área de estudo e identificado como L. dubia, corresponde a L. hirta var. hirta.

Leandra hirtella Cogn. in Mart., Eichler \& Urban, Fl. bras. 14(4): 187. $1886 . \quad$ Fig. 5d-e

Subarbustos a arbustos 0,5-1,5 m alt., nitidamente pilosos; indumento moderado a densamente setuloso-viloso, tricomas patentes, e glanduloso-granuloso. Folhas com pecíolo 0,84,8 cm compr.; lâmina 4,3-12,5 × 1,7-4,2 cm, membranácea, elíptica a ovada, base aguda a arredondada, não amplexicaule, margem inteirociliolada, ápice acuminado ou atenuado-acuminado, face abaxial com indumento sobre toda a superfície; 5 nervuras acródromas 2-12 mm suprabasais.
Tirsóides, pêndulos, não de glomérulos; brácteas e profilos não involucrais, persistentes. Flores 5meras; hipanto 1,8-2,6 mm compr., moderadamente setuloso e densamente furfuráceo-glanduloso; zona do disco glabra; lacínias do cálice eretas, as externas ca. 0,5 mm compr., as internas ca. 0,2 mm compr.; pétalas 2,1-2,8 mm compr., reflexas, oblongo-triangulares, ápice atenuado-acuminado, glabras; filetes 0,8-1,2 mm compr.; anteras $0,9-$ 1,2 mm compr., amarelas, oblongas, conectivo não prolongado, inapendiculado; ovário 3/4-ínferos, 3-locular, glabro; estilete 6,8-7 mm compr. Bacídios 2,5-5 mm compr.

Material examinado: 20.XII.1887, fl. e fr., A.F.M. Glaziou 16961 (BR, P); 27.XI.1986, fl., J.F.A. Baumgratz et al. 383 (CEPEC, FLOR, RB, US); 8.VI.1989, fr., J.F.A. Baumgratz et al. 447 (FLOR, RB, US); 20.XI.1990, fl., J.F.A. Baumgratz et al. 485 (FLOR, RB); 21.XI.1990, fl., J.F.A. Baumgratz et al. 505 (FLOR, RB); 17.I.1991, fl. e fr., J.F.A. Baumgratz et al. 542 (FLOR, RB); 17.I.1991, fr., J.F.A. Baumgratz et al. 550 (RB); 19.II.1992, fr., T.S. Pereira (RB 299543); 20.XII.1994, fl., M.L. Souza \& J.F.A. Baumgratz 1491 (FLOR, RB); 2.V.2001, fr., R.A.M. Tavares et al. 93 (FLOR, RB); 20.III.2007, fr., J.F.A. Baumgratz et al. 956A (FLOR, RB).

Material adicional examinado: BRASIL. RIO DE JANEIRO: Rio de Janeiro, 8.XII.1862, fl., A.F.M. Glaziou 586 (BR, holótipo; P, isótipo).

Endêmica do Brasil, ocorrendo em Minas Gerais, Rio de Janeiro, São Paulo, Paraná e Santa Catarina, em florestas de altitude. Na Reserva, coletada na região do Sítio Sophronites, Pedra Bicuda e Hotel Fazenda São João, entre 700-1.200 $m$ de altitude, em matas de encosta e em barrancos ao longo de estradas e trilhas, em locais sombreados ou ensolarados.

Aproxima-se de L. hirta var. hirta, conforme abordado nos comentários desta espécie, e de $L$. mollis, que se diferencia pela ausência de indumento glanduloso-granuloso e pelo maior comprimento das lacínias externas do cálice.

Leandra laevigata (Triana) Cogn. in Mart., Eichler \& Urban, Fl. bras. 14(4): 177. 1886.

Fig. 5f-g

Arbustos a arvoretas 1,2-3 m alt., aparentemente glabros, com aspecto liso e brilhante, apenas com tricomas diminutos pubérulo-glandulosos; face adaxial da lâmina foliar às vezes esparso-setulosa, tricomas caducos ou não. Folhas com pecíolo 1,3-4,8 cm compr.; lâmina 7,3-16,3 × 2-5,9 cm, membranácea, elíptica a ovada, base aguda a arredondada, margem ondulada a denticulada, nitidamente ciliolada, ápice atenuado-acuminado; domácias 
marsupiformes, axilar-primárias, ou ausentes na face abaxial; 5 nervuras acródromas 5-17,5 mm suprabasais; nervuras secundárias e de ordem superior conspícuas. Tirsóides, não de glomérulos; brácteas e profilos persistentes. Flores 5-meras; hipanto 1,5-2 mm compr.; zona do disco glabra ou esparso-setulosa; lacínias do cálice reflexas, as externas $2-2,2 \times 0,1-0,3 \mathrm{~mm}$, ápice agudo-apiculado, geralmente convoluto, as internas 0,4-0,5 mm compr.; pétalas 3,2-3,5 mm compr., reflexas, oblongas ou estreito-elípticas, ápice atenuado, glabras; filetes 1,5-1,6 mm, compr.; anteras 1,3-1,5 mm compr., alvas a cremes, oblongas, conectivo não prolongado, inapendiculado ou apêndice inconspícuo, truncado a emarginado; ovário 2/3-4/5-ínferos, 5-locular, glabro; estilete 5,5-5,8 mm compr. Bacídios 4-5,5 mm compr.

Material examinado: 21.X.1881, fl., A.F.M. Glaziou 13439 (R); 26.XI.1986, fl., J.F.A. Baumgratz et al. 376 (FLOR, RB, US); 20.XI.1990, fl. e fr., J.F.A. Baumgratz et al. 482 (FLOR, RB); 17.I.1991, fr., J.F.A. Baumgratz et al. 544 (FLOR, RB); 19.II.1992, fr., T. Sampaio (RB 299544, RB 299545); 1.V.2001, fr., R.A.M. Tavares et al. 79 (FLOR, RB); 2.V.2001, fr., R.A.M. Tavares et al. 96 (FLOR, RB); R. Guedes (RB 293879).

Endêmica do Brasil, ocorrendo em Minas Gerias, Rio de Janeiro, São Paulo, Paraná, Santa Catarina e Rio Grande do Sul. Na Reserva, foi coletada no entorno do Sítio Bacchus, Sítio Sophronites, Rio das Flores e Rio Macaé, entre 1.100-1.392 m de altitude, em matas de encosta e ao longo de trilhas, estradas e margens de rio, em locais geralmente sombreados.

Próxima de L. acutiflora, mas diferindo principalmente pela ausência de tricomas furfuráceo-estrelados e domácias em tufos de pêlos. Somente em três exemplares - Baumgratz 544 e Tavares 79, 96 - foi observada a presença de esparsos tricomas setulosos na face adaxial da lâmina foliar, uma característica também assinalada por Souza \& Baumgratz (2009) para os espécimes coletados em São Paulo.

Leandra laxa Cogn. in A. \& C. De Candolle, Mon. Phan. 7: 642. 1891.

Fig. 5h-k

Arbustos a arvoretas 0,8-5 m alt., nitidamente pilosos; indumento dos ramos, pecíolos e inflorescências moderada a densamente hirtelo e esparsamente furfuráceo-estrelado, tricomas glanduloso-granulosos ausentes; ramos achatados a subcilíndricos, nunca alados. Folhas com pecíolo 1-1,8 cm compr.; lâmina 11-14,6×3,2-4 cm, plana, membranácea, lanceolada ou elíptica, base aguda ou obtusa, não decorrente nem agudo-cuneada, margem crenulado-ciliolada, ápice acuminado, face adaxial esparso-setulosa, com maior densidade na nervura acródroma central, face abaxial moderadamente viloso-setulosa e esparsamente furfuráceo-estrelada; 5 nervuras acródromas 10$22 \mathrm{~mm}$ suprabasais. Tirsóides, às vezes ramos acessórios presentes; brácteas e bractéolas persistentes. Flores 5-meras; hipanto 2,6-3,2 mm compr., hirsuto; zona do disco setulosa, anel membranáceo ausente; lacínias do cálice reflexas, as externas $0,5-0,8(-1) \mathrm{mm}$, as internas $0,3-0,5$ mm compr.; pétalas 3,1-3,5 mm compr., reflexas, ovadas, ápice atenuado, às vezes apiculado, glabras, margem às vezes esparso cilioladosetulosa na base; estames subiguais em tamanho; filetes 1,4-2,2 mm compr.; anteras 1,7-1,9 mm compr., róseas, oblongas ou ovado-elípticas, conectivo dorsalmente giboso ou não, não prolongado, inapendiculado ou apêndice dorsal inconspícuo, agudo; ovário 3/4-ínferos, 3locular, hirtelo; estilete 5,6-6,5 mm compr. Frutos maduros não vistos.

Material examinado: 30.X.1887(1888), fl., A.F.M. Glaziou 16853 (BR, holótipo; K, P, R, isótipos); 26.XI.1986, fl. e fr., J.F.A. Baumgratz et al. 374 (FLOR, RB); 13.XI.1991, fl. e fr., T.S. Pereira (RB 296463); 22.XI.1990, fl., J.F.A. Baumgratz et al. 515 (RB); 20.XII.1994, fr., M.L. Souza \& J.F.A. Baumgratz 1505 b (FLOR, RB); 20.XII.1994, M.L. Souza \& J.F.A. Baumgratz 1516 (FLOR, RB).

Endêmica da região de Macaé de Cima, em Nova Friburgo. Na Reserva, é encontrada na região do Sítio Sophronites e Rio das Flores, entre 900$1.350 \mathrm{~m}$ de altitude, em mata de encosta ao longo de trilhas e estradas, geralmente em locais sombreados.

Exemplares de L. purpureo-villosa Hoehne, com distribuição no Sudeste e Sul do Brasil, têm sido identificados equivocadamente como L. laxa, uma espécie que se distingue principalmente pela ausência de indumento glanduloso-granuloso, brácteas e profilos menores, não involucrais, persistentes e geralmente mascarados pelo indumento, zona do disco setulosa, lacínias do cálice reflexas e pétalas maiores em comprimento (Baumgratz \& Souza 2009b). Por essa razão, acredita-se que os espécimes tratados como $L$. laxa por Camargo et al. (2009) para o Paraná, correspondem a L. purpureo-villosa.

Por características foliares, assemelha-se com L. eriocalyx, conforme abordado nos comentários desta espécie. Ilustrações também em Baumgratz \& Souza 2009b. 
Leandra magdalenensis Brade, Rodriguésia 9(18): 4,pl. 3. 1945.

Fig. 6a-d

Arbustos ca. 3,5 m alt., nitidamente pilosos; indumento dos ramos, folhas e hipanto esparsa a densamente furfuráceo-dendrítico e -estrelado, glanduloso-granuloso, às vezes resinoso, e esparsosetuloso nas folhas e hipanto, tricomas caducos ou não. Folhas com pecíolo 1-2,7 cm compr.; lâmina $5,5-8,5 \times 2,5-4,2 \mathrm{~cm}$, subcoriácea, ovada, base arredondada, margem denticulado-ciliolada, ápice agudo a acuminado, face adaxial nigrescente quando seca; 5 nervuras acródromas 1-2 $\mathrm{mm}$ suprabasais. Tirsóides; brácteas e profilos caducos, às vezes persistentes. Flores 5-meras; hipanto 2,2-4 mm compr.; zona do disco glabra; lacínias do cálice eretas, as externas $0,2-0,3 \mathrm{~mm}$ compr., as internas 0,1-0,2 mm compr.; pétalas 1,5$2 \mathrm{~mm}$ compr., reflexas, oblongo-lanceoladas, ápice agudo a atenuado, glabras; filetes $1,3-1,5 \mathrm{~mm}$ compr.; anteras 1,5-1,7 mm compr., oblongoelípticas, conectivo levemente giboso, não prolongado, inapendiculado; ovário 5/6-ínferos, 3locular, glabro; estilete 5-6 mm compr. Bacídios 5,5$6 \mathrm{~mm}$ compr., nigrescentes.

Material examinado: 20.XII.1994, fl., M.L. Souza \& J.F.A. Baumgratz 1502b (CEPEC, FLOR, K, MBM, R, RB, SPF); 1.V.2001, fr., R.A.M. Tavares et al. 82 (FLOR, RB).

Material adicional examinado: BRASIL. RIO DE JANEIRO: Santa Maria Madalena, 3.III.1934, fl. e fr., A.C. Brade \& Santos Lima 13221 a (RB, holótipo e isótipos).

Endêmica do Rio de Janeiro, sendo encontrada em Macaé de Cima e no Parque Estadual do Desengano, no município de Santa Maria Madalena, que integram a cadeia montanhosa da Serra dos Órgãos. Primeiro registro para a Reserva, sendo encontrada na área dos Sítios Sophronites e Bacchus, entre 1.100-1.550 m de altitude, em local sombreado na borda da mata de encosta.

Espécie rara e de formações de altitude, representando a coleção de Macaé de Cima as únicas coletas após a do material-tipo. Pela presença de tricomas glanduloso-granulosos aproxima-se de $L$. gracilis, $L$. multisetosa e $L$. riedeliana, porém, distingue-se destas três espécies por apresentar tricomas dendríticos nas partes vegetativas e no hipanto.

Leandra melastomoides Raddi, Mem. Soc. Ital. Fis. 18: 386. 1820.

Fig. 6e-f

Subarbustos a arbustos $0,7-1 \mathrm{~m}$ alt., nitidamente pilosos; indumento dos ramos, pecíolos e inflorescências hispídulo-estriguloso; nos ramos, tricomas menores ou iguais a 1,1 mm compr., adpresso- ascendentes. Folhas com pecíolo 0,3-1 cm compr.; lâmina 5,2-12,4 × 1,5-4,3 cm, papirácea a cartácea, elíptica, base agudo- a obtuso-cuneada ou arredondada, não amplexicaule, margem inteira a crenulada, ciliolada, ápice agudo a acuminado, face adaxial plana a bulada, estrigulosa-estrigosa, hispídula nas nervuras acródromas, face abaxial plana a foveolada, setuloso-setosa, às vezes também vilosa, hispídula nas nervuras acródromas; 3(-5) nervuras acródromas 5-18 mm suprabasais. Tirsóides de glomérulos; brácteas e profilos vinosos, involucrais, persistentes na frutificação, brácteas mais externas com a face adaxial glabra e abaxial hispídulo-adpressa em toda a superfície. Flores 6-meras; hipanto 3,5$4 \mathrm{~mm}$ compr., densamente híspido-adpresso; zona do disco glabra; lacínias do cálice eretas, as externas ca. $2 \mathrm{~mm}$ compr., as internas ca. $1,2 \mathrm{~mm}$ compr., glabras, margem às vezes com esparsos tricomas; pétalas ca. 4,5 mm compr., eretas, oblongas, ápice atenuado, glabras; estames de dois tamanhos, ante-sépalos com filetes 4-4,5 mm compr., anteras ca. 3,8 $\mathrm{mm}$ compr., antepétalos com filetes 3,5-4 mm compr., anteras 3,43,5 mm compr., ambos com anteras ovadas, extrorsamente falciformes, conectivo prolongado, apêndice truncado ou bi-denticulado; ovário 1/51/2-ínfero, 4-locular, setuloso; estilete 11,5-13 mm compr. Frutos maduros não vistos.

Material examinado: fl. e fr., G. Raddi (RB, foto do holótipo); 16.I.1991, fl. e fr., J.F.A. Baumgratz et al. 530 (RB);20.XII.1994, fl., M.L. Souza \& J.F.A. Baumgratz 1488b, 1494 (FLOR, RB); 2.V.2001, fr., R.A.M. Tavares et al. 87 (FLOR, RB). 2.V.2001, fr., R.A.M. Tavares et al. 91 (RB).

Distribui-se no Brasil, pelos estados de Goiás, Paraíba, Bahia, Minas Gerais, Espírito Santo, Rio de Janeiro, São Paulo, Paraná e Santa Catarina e, segundo Wurdack (1962), de ocorrência duvidosa no Pará e Suriname. Primeiro registro na Reserva, sendo encontrada no entorno do Sítio Bacchus, Sítio Sophronites e Hotel Fazenda São João, entre 980 $1.100 \mathrm{~m}$ de altitude, em locais sombreados na borda de matas de encosta ao longo de trilhas e estradas.

Essa espécie tem sido usualmente descrita com flores hexâmeras (Cogniaux 1886, 1891; Wurdack 1962; Romero 1993), como no presente estudo. Porém, Souza \& Baumgratz (2009) assinalam, para a flora de São Paulo, haver raramente flores pentâmeras.

Aproxima-se de L. amplexicaulis, L. fragilis e L. glazioviana, conforme abordado nos comentários destas espécies. Entretanto, assemelha-se mais a $L$. fragilis, que difere, principalmente, pelas brácteas mais externas do invólucro com a face abaxial glabra ou com tricomas restritos à região da nervura central. 


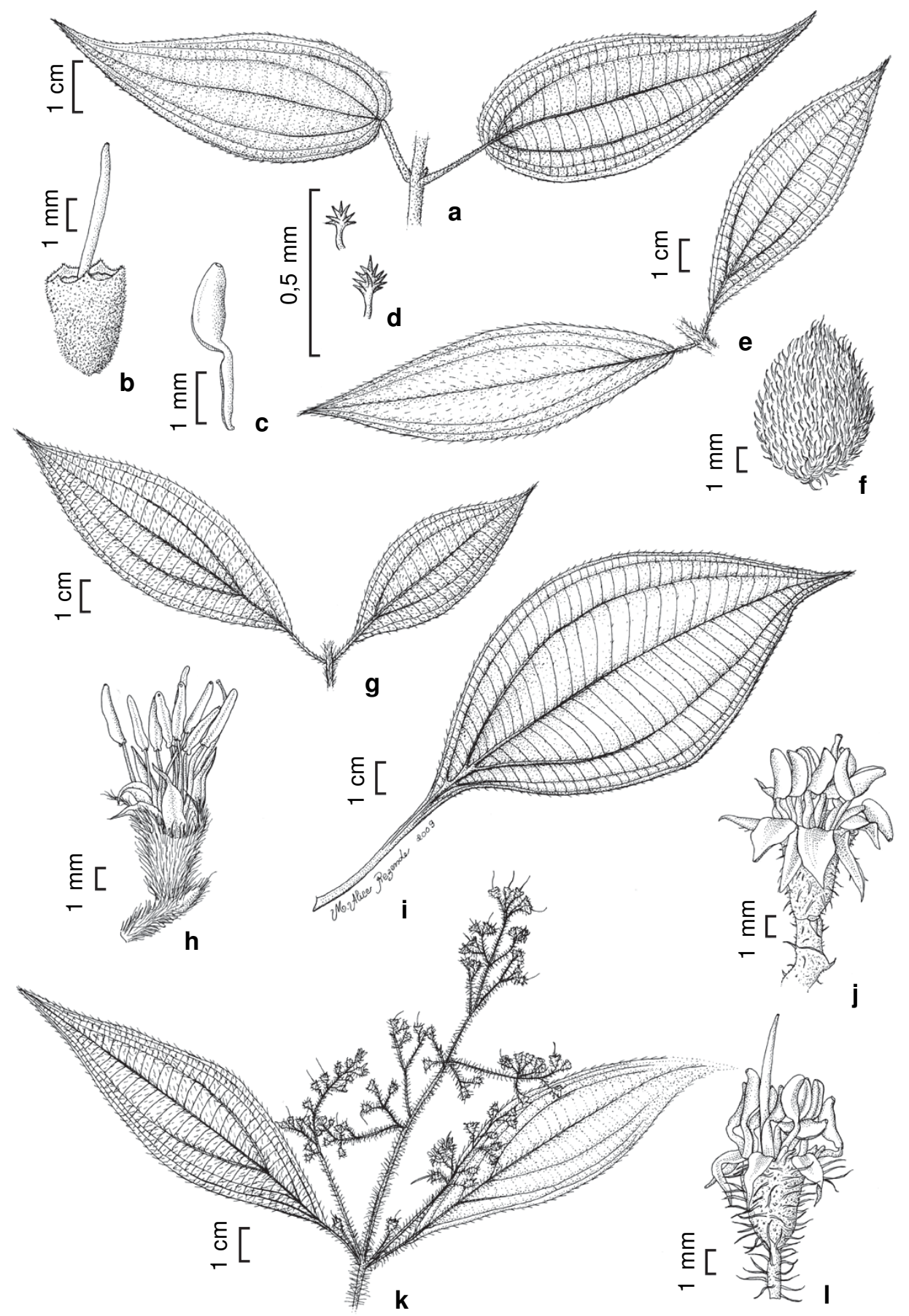

Figura 6 - a-d. Leandra magdalenensis Brade - a. folhas; b. hipanto, cálice e estilete; c. estame; d. tricomas furfuráceodentríticos. e-f. Leandra melastomoides Raddi - e. folhas; f. bráctea, face abaxial. g-h. Leandra mollis Cogn. - g. folhas; h. flor. i-j. Leandra multiplinervis (Naudin) Cogn. - i. folha; j. flor e profilos. k-1. Leandra multisetosa Cogn. - k. detalhe do ramo florífero; 1. flor e profilo. (a-d Souza \& Baumgratz 1502b; e-f Souza \& Baumgratz 1494; g Baumgratz et al. 958; h Glaziou 3965; i-j Baumgratz et al. 370; k-1 Baumgratz et al. 375).

Figure 6 - a-d. Leandra magdalenensis Brade - a. leaves; b. hypanthium, calyx, and style; c. stamen; d. dendritic-furfuraceous trichomes. e-f. Leandra melastomoides Raddi - e. leaves; f. bract, abaxial surface. g-h. Leandra mollis Cogn. - g. leaves; h. flower. $\mathrm{i}-\mathrm{j}$. Leandra multiplinervis (Naudin) Cogn. - i. leaf; j. flower and prophylls. k-1. Leandra multisetosa Cogn. - k. detail of the flowering branch; 1. flower and prophyll. 
Leandra mollis Cogn. in Mart., Eichler \& Urban, Fl. bras. 14(4): 126, tab. 29, fig. 1. $1886 . \quad$ Fig. 6g-h

Subarbustos a arbustos 0,7-2,5 m alt., nitidamente pilosos; indumento dos ramos, folhas, inflorescências e hipanto e lacínias externas do cálice densamente seríceo-setuloso, tricomas adpressos. Folhas geralmente anisófilas; pecíolo 0,6-2,6 cm compr.; lâmina (4,5-)7-12,5×(1,7-)2-4cm, membranácea, elíptica a estreito-ovada, base aguda a obtusa, não amplexicaule, margem crenuladociliolada, ápice atenuado-acuminado, indumento alvo-rosado sobre as nervuras acródromas e nos bordos; 5 nervuras acródromas 6-18 mm supabasais. Tirsóides, não de glomérulos; brácteas e profilos não involucrais, persistentes. Flores 5-meras; hipanto 2,3-2,5 mm compr.; zona do disco glabra; lacínias do cálice eretas, as externas 1,7-2,1 mm compr., as internas 0,4-0,5 mm compr., glabras; pétalas 44,6 mm compr., eretas, oblongo-triangulares, ápice atenuado-acuminado, glabras; estames desiguais em tamanho; filetes 3,5-5,2 mm compr.; anteras 22,6 mm compr., oblongas, ápice obtuso, conectivo prolongado, apêndice inconspícuo, agudo, truncado a emarginado ou trilobado; ovário $1 / 2$ ínfero, glabro; estilete 6-8,2 mm compr. Bacídios 5-7 mm compr.

Material examinado: 19.II.1888, fl. e fr., A.F.M. Glaziou 16862 (P-3x, R, RB); 12.III.1870, fl. e fr., A.F.M. Glaziou 3965 (P-2x, R); 3.V. 1988, fr., J.F.A. Baumgratz et al. 408 (FLOR, RB, US); 6.VI.1993, fr., C.M. Vieira \& L.C. Gurken 265 (FLOR, RB); 20.XII.1994, M.L. Souza \& J.F.A. Baumgratz 1509 (FLOR, RB); 2.V.2001, fr., R.A.M. Tavares et al. 89, 95 (FLOR, RB); 20.III.2007, fr., J.F.A. Baumgratz et al. 958 (CEPEC, FLOR, MBM, RB).

Endêmica da região de Macaé de Cima, em Nova Friburgo, onde ocorre em áreas próximas aos Sítios Sophronites e São João e Rio Macaé, entre 700-1.100 m de altitude, em formações de encostas margeando estradas e trilhas, em locais sombreados, além da margem da estrada para Rio Bonito.

Assemelha-se vegetativamente a $L$. hirta var. hirta e L. hirtella, conforme já abordado nos comentários destas espécies.

Leandra multiplinervis (Naudin) Cogn. in Mart., Eichler \& Urban, Fl. bras. 14(4): 180. 1886. Fig. 6i-j

Arbustos a arvoretas 1-3 m alt., nitidamente pilosos ou aparentemente glabros; indumento dos ramos, pecíolos, face abaxial das folhas, inflorescências e hipanto esparso-setuloso e furfuráceo-estrelado, tricomas cedo caducos, tricomas glandulosogranulosos ausentes; ramos achatados a subcilíndricos, sulcados quando jovens, nunca alados. Folhas com pecíolo 1,2-5,8 cm compr., alado para o ápice; lâmina $(8,5-) 11,5-32 \times(3,5-) 5,3-16,5 \mathrm{~cm}$, papirácea, elíptica, base longo-decorrente, margem crenulado-ciliolada, ápice agudo-acuminado, face adaxial plana, setulosoadpressa, estrigulosa e furfuráceo-estrelada, principalmente nas nervuras acródromas, tricomas estrelados caducos; 5-7 nervuras acródromas 45$80 \mathrm{~mm}$ suprabasais. Tirsóides; brácteas e profilos persistentes. Flores 5-meras; hipanto (3-)3,5-3,8 mm compr.; zona do disco glabra ou raros tricomas setulosos; lacínias do cálice reflexas, as externas 3$5 \mathrm{~mm}$ compr., as internas $0,3-0,5 \mathrm{~mm}$ compr.; pétalas 3,5-5 mm compr., reflexas, ovadas a elípticas, ápice atenuado, glabras; filetes $2,5-3 \mathrm{~mm}$ compr.; anteras 2,2-2,8 mm compr., alvas, às vezes alvo-amareladas, posteriormente rosadas, ovado-oblongas, conectivo não prolongado, inapendiculado ou apêndice inconspícuo, calcarado; ovário ínfero ou 4/5-5/6ínferos, 3-locular, glabro ou raros tricomas setulosos; estilete $8-10 \mathrm{~mm}$ compr. Frutos maduros não vistos. Material examinado: $30 . X .1887$, fl. e fr., A.F.M. Glaziou 16873 (P); 22.IX.1888, fl. e fr., A.F.M. Glaziou 17532 (P); 18.X.1977, fl. e fr., P.J.M. Maas et al. 3295 (RB); 25.X.1986, fl. e fr., G. Martinelli \& M. Leitman 11805 (FLOR, RB); 18.IX.1986, fl., C. Farney et al. 1221 (FLOR, RB); 25.XI.1986, fl. e fr., J.F.A. Baumgratz et al. 370 (FLOR, RB, US); 27.XI.1986, fl. e fr., J.F.A. Baumgratz et al. 384 (FLOR, RB); 24.V.1988, fl., S.V.A. Pessoa et al. 312 (RB); 7.XI.1988, fl., R. Guedes et al. 2192 (RB); 13.IX.1989, fl., A. Fonseca Vaz et al. 683 (FLOR, RB); 20.XI.1990, fl. e fr., J.F.A. Baumgratz et al. 483 (FLOR, RB); 16.XII.1991, fl. e fr., M. Nadruz et al. 722 (FLOR, RB); 6.XI.1993, fl. e fr., C.M. Vieira \& L.C. Gurken 443 (RB); 14.12.2001, fl. e fr., R.A.M. Tavares et al. 99 (FLOR, RB); R. Guedes et al. $2119 b$ (RB).

Espécie de ampla distribuição, ocorrendo no México, Guatemala e Brasil, nos estados do Rio de Janeiro, São Paulo e Paraná, geralmente em formações vegetacionais de altitude. Na Reserva foi coletada frequentemente no entorno do Sítio Sophronites, Rio das Flores e Fazenda Ouro Verde, entre $1.100-1.250 \mathrm{~m}$ de altitude, em locais sombreados de matas de encosta e um pouco mais ensolarados ao longo de margens de rios, estradas e trilhas.

Facilmente reconhecida no campo pela base da lâmina foliar acentuadamente decorrente e pelos tricomas setulosos muito esparsos.

Leandra multisetosa Cogn. in A. \& C. De Candolle, Mon. Phan. 7: 632. 1891.

Fig. 6k-1

Subarbustos, arbustos ou arvoretas 0,7-4 m alt., nitidamente pilosos; indumento dos ramos, pecíolos, face abaxial das folhas, inflorescências e hipanto hirtelo, glanduloso-granuloso e furfuráceo- 
estrelado. Folhas com pecíolo 0,7-2,2 cm compr.; lâmina 9-12,2×3,8-4,8 cm, membranácea, elíptica ou estreito-ovada, base agudo-cuneada a arredondada, margem ondulada a crenulado-ciliada, ápice acuminado a atenuado-acuminado, face adaxial esparsa a densamente setulosa na nervura acródroma central e extremidade dos bordos e glanduloso-granulosa; 5-7 nervuras acródromas 13$30 \mathrm{~mm}$ suprabasais. Tirsóides, ramos acessórios presentes; brácteas e profilos persistentes. Flores 5-meras; zona do disco glabra; hipanto 2-2,5 mm compr.; lacínias do cálice eretas a patentes, as externas $0,4-0,5 \mathrm{~mm}$ compr., as internas $0,4-0,5 \mathrm{~mm}$ compr., ciliado-setulosas, pétalas $2-2,3 \mathrm{~mm}$, reflexas, oblongo-triangulares, ápice atenuado-acuminado, glabras; filetes 1,4-1,5 mm compr.; anteras 1,4-1,6 $\mathrm{mm}$ compr., extrorsamente curvas, oblongas, conectivo prolongado, inapendiculado; ovário 5/6-ínferos, 3locular, glabro; estilete 5,5-6,3 mm compr. Bacídios 6-7 mm compr.

Material examinado: 30.X.1887(1888), fl., A.F.M. Glaziou 16828 (BR, holótipo; K, P-3x, R, isótipos); 26.XI.1986, fl., J.F.A. Baumgratz et al. 375 (CEPEC, FLOR, K, MBM, RB); 20.XI.1990, fl., J.F.A. Baumgratz et al. 486 (FLOR, RB); 17.I.1991, fr., J.F.A. Baumgratz et al. 537 (RB); 19.II.1992, fr., T.S. Pereira s.n. (FLOR 36084).

Endêmica da região de Macaé de Cima, em Nova Friburgo, onde ocorre na região do Sítio Sophronites e Rio das Flores, entre 1.000-1.100 m de altitude, em locais sombreados na mata de encosta ao longo de trilhas e estradas e em margens de rios. Recoletada após ca. 100 anos da coleta do exemplar-tipo, sendo considerada uma espécie em perigo de extinção.

Assemelha-se a L. gracilis, conforme abordado nos comentários desta espécie.

Leandra nianga (DC.) Cogn. in Mart., Eichler \& Urban, Fl. bras. 14(4): 96. 1886.

Fig. 7a-b

Arbustos ca. $70 \mathrm{~cm}$ alt., nitidamente pilosos; indumento dos ramos, pecíolo, inflorescências e hipanto esparsa a moderadamente hirsuto, tricomas dos ramos e pecíolos 3-7,5 $\mathrm{mm}$ compr., frequentemente vinosos, e furfuráceo-estrelados, tricomas glanduloso-granulosos ausentes; ramos achatados a subcilíndricos, nunca alados. Folhas com pecíolo 2,8-3,8 cm compr.; lâmina 7,5-12×3$5,2 \mathrm{~cm}$, plana ou ondulada, membranácea, ovada, base obtusa a arredondada ou subcordada, não decorrente nem agudo-cuneada, margem crenuladociliada, ápice acuminado, face adaxial moderadamente setosa e raros tricomas estrelados, caducos, face abaxial esparsamente setuloso-setosa e estreladofurfurácea, ambas com tricomas vinosos; 5 nervuras acródromas 2-4 mm suprabasais. Tirsóides; brácteas e profilos persistentes. Flores 5-meras; hipanto 4-4,2 mm compr.; zona do disco glabra ou moderadamente setulosa, anel membranáceo ausente; lacínias do cálice reflexas, as externas $3-4 \mathrm{~mm}$ compr., as internas (1-)1,7-2 mm compr.; pétalas 3-3,3 mm compr., reflexas, oblongas, ápice agudoapiculado, glabras; filetes 2,2-2,8 $\mathrm{mm}$ compr.; anteras 2,5-2,7 mm compr., amarelas, atenuadas, conectivo não prolongado, inapendiculado; ovário 3/4-2/3-ínferos, 3-locular, com esparsos e diminutos tricomas estrelados; estilete 7,5-7,8 mm compr. Frutos maduros não vistos.

Material examinado: 16.I.1991, fr., J.F.A. Baumgratz et al. 523 (RB); 14.XII.2001, fl. e fr., R.A.M. Tavares et al. 98, 100 (FLOR, RB); 21.III.2007, fr., J.F.A. Baumgratz et al. 962 (FLOR, RB).

Material adicional examinado: BRASIL. RIO DE JANEIRO: Santa Maria Madalena, 24.XI.1977, fr., J.P.P. Carauta 2757 (FLOR, RB).

Endêmica do Brasil, ocorrendo em Minas Gerais, Rio de Janeiro e São Paulo, geralmente em formações vegetacionais de altitude. Primeiro registro para a Reserva, coletada na região próxima ao Sítio Bacchus, Hotel Fazenda São João e Hotel Garlipi, entre 800-1.000 m de altitude, em matas de encosta ao longo de trilhas e estradas, em locais sombreados, e frequentemente destacando-se no ambiente pela coloração vinosa do indumento nos ramos, folhas e inflorescências.

Espécie muito semelhante vegetativamente a L. xanthostachya, que se diferencia, principalmente, pela frequente coloração amarela do indumento e maior comprimento das lacínias do cálice.

Algumas características florais mostram-se diferentes do observado por Souza \& Baumgratz (2009) para essa espécie na flora de São Paulo, como a zona do disco apenas pilosa, o ovário glabro (talvez pelos tricomas estrelados serem esparsos e diminutos, podendo cair facilmente) e o maior comprimento do estilete (12-13 mm). Essas diferenças possivelmente se justificam pelo pouco material coletado na Reserva.

Leandra purpurascens (DC.) Cogn. in Mart., Eichler \& Urban, Fl. bras. 14(4): 110. 1886.

Fig. 7c-d

Arbustos $0,7-4 \mathrm{~m}$ alt., nitidamente pilosos; indumento dos ramos, pecíolos, inflorescências e hipanto esparsa a moderadamente hirtelo, tricomas dos ramos até $2 \mathrm{~mm}$ compr., e esparsamente furfuráceo-estrelado, tricomas glanduloso-granulosos ausentes; ramos subcilíndricos a cilíndricos, nunca 


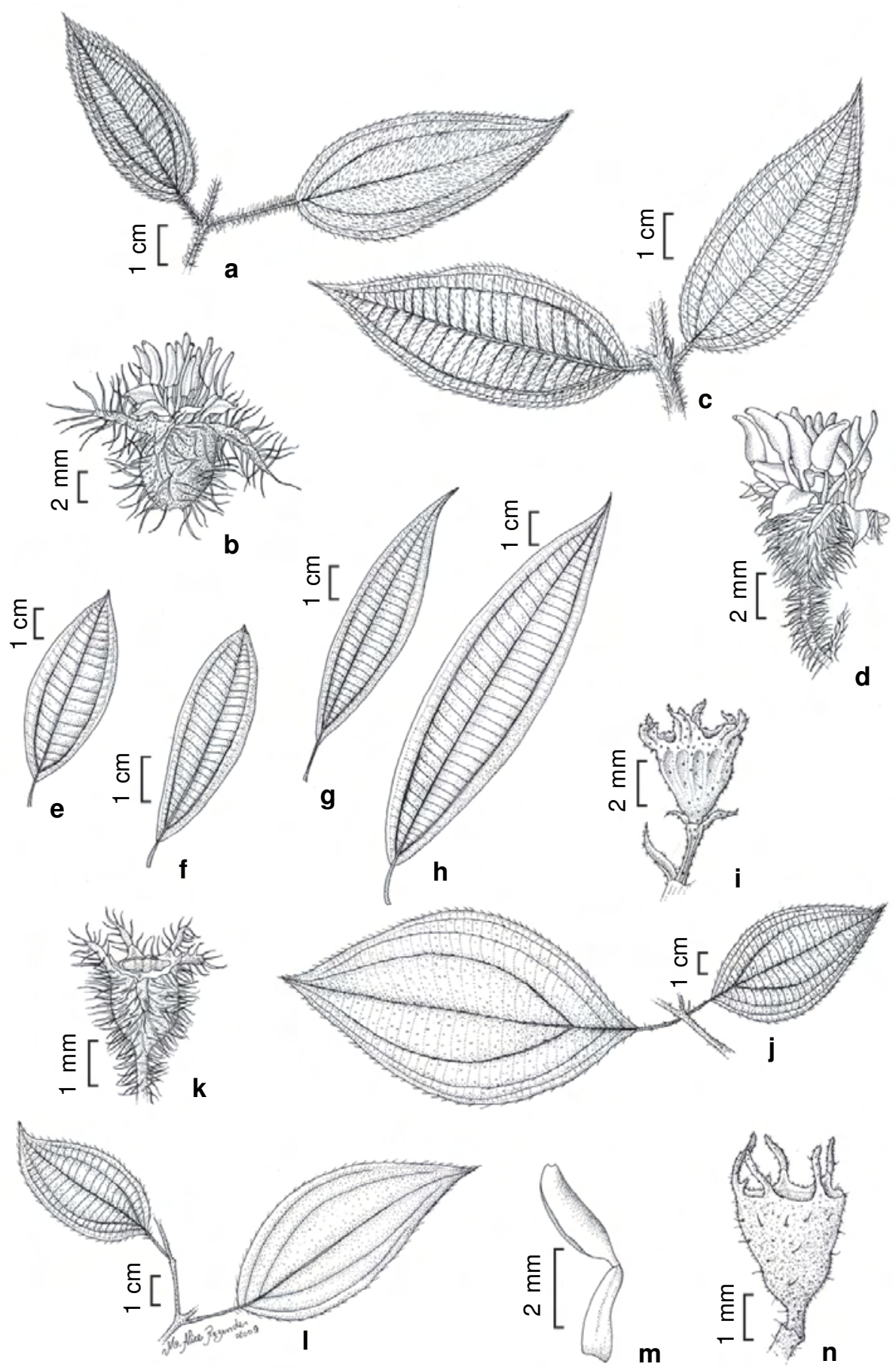

Figura 7 -a-b. Leandra nianga (DC.) Cogn. - a. folhas; b. flor. c-d. Leandra purpurascens (DC.) Cogn. - c. folhas; d. flor. e-i. Leandra quinquedentata (DC.) Cogn. - e-h. folhas, variação morfológica; i. fruto jovem, bráctea e profilos. j-k. Leandra regnellii (Triana) Cogn. $-\mathrm{j}$. folhas; $\mathrm{k}$. fruto jovem. 1-n. Leandra riedeliana (O.Berg ex Triana) Cogn. - 1 . folhas; $\mathrm{m}$. estame; n. fruto jovem. (a-b Tavares et al. 100; c-d Correia et al. 179; e, i Araujo et al. 45; f Leitman et al. 200; g Baumgratz et al. 541; h Baumgratz et al. 466; j-k Glaziou 17535; 1-n Damazio s.n., RB 44306).

Figure 7 - a-b. Leandra nianga (DC.) Cogn. - a. leaves; b. flower. c-d. Leandra purpurascens (DC.) Cogn. - c. leaves; d. flower. e-i. Leandra quinquedentata (DC.) Cogn. - e-h. leaves, morphological variation; i. young fruit, bract, and prophylls. j-k. Leandra regnellii (Triana) Cogn. - j. leaves; k. young fruit. 1-n. Leandra riedeliana (O.Berg ex Triana) Cogn. - 1. leaves; m. stamen; $n$. young fruit. 
alados. Folhas com pecíolo (0,2-)0,5-1,6 cm compr.; lâmina $(2,2-) 4,8-12,7 \times(0,7-) 1,9-4,7 \mathrm{~cm}$, plana, membranácea a cartácea, elíptica a ovada, base aguda a arredondada, não decorrente nem agudo-cuneada, margem ondulada ou crenulada, densamente cilioladoadpressa, ápice agudo-atenuado a acuminado, face adaxial moderadamente setuloso-setosa ou estrigulosa e furfuráceo-estrelada, face abaxial moderada a densamente viloso-setulosa e esparsamente furfuráceo-estrelada; 3-5 nervuras acródromas (1-) 1,5-8 mm suprabasais. Tirsóides; brácteas e profilos persistentes. Flores 5-meras; hipanto ca. 2,8 mm compr.; zona do disco setulosa, anel membranáceo ausente; lacínias do cálice reflexas, as externas 2,8-3 mm compr., as internas $0,5-1,2 \mathrm{~mm}$ compr.; pétalas ca. $3,5 \mathrm{~mm}$ compr., reflexas, ovadas, ápice agudo, glabras; filetes 2,3-2,6 mm compr.; anteras 2,1-2,5 mm compr., amarelas, atenuadas, conectivo não prolongado, giboso ou não no dorso, base truncada ou emarginada, inapendiculado; ovário 1/2-ínfero, 3locular, setuloso; estilete ca. 7,3 mm compr. Frutos maduros não vistos.

Material examinado: 12.IX.1990, fl., C.M.B. Correia et al. 179 (FLOR, RB); 16.I.1991, fl. e fr., J.F.A. Baumgratz et al. 527 (RB); 20.XII.1994, fr., M.L. Souza \& J.F.A. Baumgratz 1502 (FLOR, RB); 20.XII.1994, fl., M.L. Souza \& J.F.A. Baumgratz 1503 (FLOR, RB); 14.XII.2001, fl. e fr., R.A.M. Tavares et al. 102 (RB); $R$. Guedes et al. (RB 293877).

Endêmica do Brasil, ocorrendo no Piauí, Paraíba, Minas Gerais, Rio de Janeiro, São Paulo, Paraná, Santa Catarina e Rio Grande do Sul. Primeiro registro para a Reserva, onde foi coletada no entorno dos Sítios Bacchus, Fazenda Velha e Sophronites e do Hotel Fazenda São João, entre 850$1.100 \mathrm{~m}$ de altitude, em matas de encosta, ao longo de estradas e em áreas perturbadas e ensolaradas, apresentando geralmente indumento vinoso.

Espécie afim de L. eriocalyx e L. fallax, conforme abordado nos comentários dessas espécies.

Leandra quinquedentata (DC.) Cogn. in Mart., Eichler \& Urban, Fl. bras. 14(4): 156. 1886.

Fig. 7e-i

Subarbustos, arbustos ou arvoretas $0,7-5 \mathrm{~m}$ alt., aparentemente glabros; indumento esparsa a densamente glanduloso-granuloso, obscurecendo ou não tricomas furfuráceo-estrelados, estes geralmente caducos. Folhas com pecíolo 0,5-3 cm compr.; lâmina 4-20,2 × 1,5-5 cm, subcartácea a cartácea, elíptica, às vezes obovada, raro oblonga, base aguda a obtusa, margem inteira a crenulada, geralmente revoluta, ápice agudo a acuminado; domácias ausentes; 3 nervuras acródromas basais ou até ca. $3 \mathrm{~mm}$ suprabasais, as laterais muito próximas ou confluentes às margens na base. Tirsóides; brácteas e profilos persistentes. Flores 5-meras; hipanto 2,6-3,5(-4) mm compr.; zona do disco setulosa; cálice distintamente laciniado, nunca truncado, lacínias eretas, as externas $0,7-1,9 \times 0,2$ $0,5 \mathrm{~mm}$, giboso-geniculadas, ápice acuminadoapiculado, as internas 0,3-1,1 mm compr., largamente ovadas ou triangulares; pétalas 2,6-4,2 mm compr., reflexas, ovadas, elípticas ou oblongas, ápice atenuado-agudo, às vezes apiculado, geralmente na face abaxial com esparsos tricomas glandulares longopedicelados, caducos; filetes $2-3 \mathrm{~mm}$ compr.; anteras 1,5-2,6 mm compr., ovadas, elípticas, oblongas ou levemente obovadas, conectivo giboso no dorso, prolongado, inapendiculado ou apêndice inconspícuo, agudo ou bilobado; ovário 1/2-3/5ínferos, 3-locular, glabro ou esparso-setuloso; estilete 5,4-6,5(-8,5) mm compr. Bacídios 6-10 mm compr.

Material examinado: 20.XII.1887, fl. e fr., A.F.M. Glaziou 16924 (R); 24.VIII.1986, fl. e fr., M. Leitman et al. 200 (FLOR, RB); 2.V.1988, fl. e fr., J.F.A. Baumgratz et al. 391 (CEPEC, RB); 25.V.1989, fl. e fr., G. Martinelli et al. 13437 (RB); 8.VI.1989, fr., J.F.A. Baumgratz et al. 445 (CEPEC, FLOR, RB, US); 16.VIII.1989, fl., I.A. Araujo et al. 45 (FLOR, RB, US); 3.VI.1990, fr., S.V.A. Pessoa et al. 524 (CEPEC, FLOR, MBM, RB); 13.VIII.1990, fl. e fr., C.M.B. Correia et al. 102 (FLOR, RB); 17.VIII.1990, fr., J.F.A. Baumgratz et al. 466 (RB); 19.VIII.1990, fl. e fr., J.F.A. Baumgratz et al. 480 (CEPEC, RB); 17.I.1991, fl., J.F.A. Baumgratz et al. 541 (RB); 17.I.1991, fl., J.F.A. Baumgratz et al. 547 (FLOR, RB); 23.I.1994, fl., C.M. Vieira \& L.C. Gurken 532 (MBM, RB); 1.V.2001, fl. e fr., R.A.M. Ttavares et al. 83 (RB).

Endêmica do Brasil, ocorrendo na Bahia, Minas Gerais, Rio de Janeiro, São Paulo, Santa Catarina e Rio Grande do Sul. Na Reserva, foi coletada no entorno dos Sítios Bacchus, Sophronites e Fazenda Velha, Pedra Bicuda, Serra dos Pirineus, Rio Macaé, Rio das Flores, Fazenda Ouro Verde, Hotel Fazenda São João, entre 1.000-1.500 m de altitude, crescendo em matas de encosta ao longo de trilhas e estradas e em mata nebular, em locais sombreados e ensolarados. Espécimes coletados em mata nebular (Baumgratz 480, Leitman 200) apresentam folhas com dimensões menores, consistência mais rígida e margem mais nitidamente crenulada do que as amostras coletadas em cotas altitudinais mais baixas.

A possível ocorrência de $L$. neurotricha na Reserva está baseada nos espécimes Glaziou 8376, 16008 e 16923, cujas coletas teriam sido feitas na Serra dos Órgãos e em Macaé de Cima (Glaziou 1908). O exemplar Glaziou 8376 (P, isótipo; F, RB, fotos), apesar de estar corretamente identificado, pois possui brácteas e profilos diagnósticos para esta 
espécie, ou seja, de grandes dimensões, naviculares e caducos, foi coletado na serra da Bocaina. Já os espécimes Glaziou 16008 (R), coletado na Serra dos Órgãos, e Glaziou 16923 (P), em Macaé de Cima, correspondem a $L$. quinquedentata, uma vez que apresentam brácteas e profilos de pequenas dimensões, lineares, nunca naviculares, e persistentes.

Aproxima-se de L. barbinervis, conforme abordado nos comentários desta espécie, e, pelas mesmas características, ou seja, o aspecto aparentemente glabro da planta e morfologia das folhas, de L. truncata. Esta facilmente se diferencia pelo cálice truncado-ondulado a -denticulado, com lacínias inconspícuas.

Leandra regnellii (Triana) Cogn. in Mart., Eichler \& Urban, Fl. bras. 14(4): 116. $1886 . \quad$ Fig. 7j-k

Arbustos nitidamente pilosos; indumento dos ramos, pecíolos, inflorescências e hipanto esparsa a densamente hirtelo e furfuráceo-estrelado, tricomas glanduloso-granulosos ausentes; ramos achatados a cilíndricos, nunca alados. Folhas com pecíolo ca. 4 cm compr.; lâmina ca. $23 \times 15,2 \mathrm{~cm}$, membranácea, ovada, base agudo-cuneada, margem crenulado- a serrulado-ciliolada, ápice agudo- ou atenuadoacuminado, ambas as faces moderada a densamente furfuráceo-estrelada, face adaxial bulada, também moderado-estrigulosa no limbo e setuloso-adpressa nas nervuras acródromas, face abaxial foveolada, também vilosa ou setuloso-vilosa; 7 nervuras acródromas 40-43 mm suprabasais. Tirsóides, terminais e/ou pseudo-axilares; brácteas e profilos persistentes. Flores 5-meras; hipanto ca. $3 \mathrm{~mm}$ compr.; zona do disco glabra ou setulosa; lacínias do cálice eretas a reflexas, as externas $0,5-2,2 \mathrm{~mm}$ compr. as internas inconspícuas ( $0,1-0,2 \mathrm{~mm}$ compr.); pétalas 2-2,5 $\mathrm{mm}$ compr., reflexas, oblongotriangulares, ápice agudo-atenuado, glabras; filetes 1,3-2,2 mm compr.; anteras 1-2,6 mm compr., amarelas, oblongo-subuladas, conectivo prolongado ou não, inapendiculado; ovário 1/2-3/5-ínferos, 3(-5)-locular, piloso; estilete 4,5-6,5 mm compr. Bacídios 4-4,5 mm compr.

Material examinado: 21.X.1888 (1889), fl., A.F.M. Glaziou 17535 (BR, K, P).

Material adicional examinado: BRASIL. RIO DE JANEIRO: Teresópolis, 22.I.1888, fr., A.F.M. Glaziou (P 00116879); 27.I.1888, fl. e fr., A.F.M. Glaziou 16871 (K, P-2x); Serra dos Órgãos à Taboinha, 27.I.1888, fl., A.F.M. Glaziou 16871 ( (P). Mun. indet., fr., J.T. Moura 166 (RB, US - fotos de B); fl. e fr., A. Loefgren 776 (P). SANTA CATARINA: Blumenau, IX.1888, fl., E. Ule 910 (US, isosíntipo de L. schenkii Cogn.). S. loc., fl., F. Sellow 3867 (US, isosíntipo de L. alterninervia Cogn.).
Distribui-se no Brasil, desde Minas Gerais até o Rio Grande do Sul (Wurdack 1962), entre 200-1.000 m de altitude, na Argentina (Lucena 1983), Paraguai e Bolívia (http://www.tropicos.org, periodicamente atualizado). A ocorrência dessa espécie em Macaé de Cima está baseada apenas na citação de Glaziou (1908) e em Glaziou 17535 (BR, P). Embora seja o primeiro registro para a Reserva sob o nome $L$. regnellii, este espécime foi identificado por Cogniaux (1891) como L. schwackei. Pelas semelhanças morfológicas, estas espécies correspondem, provavelmente, a um único táxon, porém a indisponibilidade até o momento de um exemplar-tipo de L. regnellii não possibilita ainda uma resolução segura. Leandra alterninervia e $L$. schenckii já foram corretamente consideradas sinônimos de L. regnelli por Wurdack (1962).

De acordo com a descrição original (Cogniaux 1886), L. regnellii tem ovário glabro. Porém, ovário piloso nesta espécie também foi observado por Souza \& Baumgratz (2009) em espécimes coletados em São Paulo.

Leandra riedeliana (O.Berg ex Triana) Cogn. in Mart., Eichler \& Urban, Fl. bras. 14(4): 164. 1886.

Fig. 7l-n

Arbustos 1-1,5m (Cogniaux 1886), nitidamente pilosos; indumento dos ramos, folhas, inflorescências e hipanto denso furfuráceo-estrelado e glandulosogranuloso, às vezes com tricomas setulosos esparsos, caducos. Folhas com pecíolo 0,8-1,6 cm compr.; lâmina 4-6,3 × 1,3-2,5 cm, papirácea, lanceolada a elíptica, base arredondada, margem inteira a crenulada, ciliolada, ápice atenuado-acuminado, face abaxial também esparsamente setulosa nas nervuras acródromas; 5(-7) nervuras acródromas 2-5 mm suprabasais. Tirsóides; brácteas e profilos caducos. Flores 5-meras; hipanto 2-2,5 mm compr.; zona do disco glabra; lacínias do cálice eretas, persistentes, as externas 1,2$1,3 \mathrm{~mm}$ compr., as internas $0,3-0,5 \mathrm{~mm}$ compr.; pétalas ca. $2 \mathrm{~mm}$ compr., reflexas, triangulares, ápice atenuado, glabras; filetes 1,7-1,8 mm compr.; anteras 1,3-1,5 mm compr., oblongas, conectivo giboso no dorso, prolongado, inapendiculado; ovário 3/4-ínferos, 3locular, glabro; estilete 5,4-5,5 mm compr. Frutos maduros não vistos.

Material examinado: 20.XII.1887, fl. e fr., A.F.M. Glaziou 16919 (P).

Material adicional examinado: BRASIL. MINAS GERAIS: L. Damazio (RB 44306); serra do Chapadão, 9.II.1890, P. Schwacke 6730 (RB). RIO DE JANEIRO: IV.1883, A.F.M. Glaziou 13846 (K, P, síntipos). SÃO PAULO: Cunha, 7.XII.1952, F. Markgraf \& A.P.Duarte 10363 (RB). 
Endêmica do Brasil, ocorrendo em Minas Gerais, Rio de Janeiro e São Paulo. Primeiro registro para a Reserva, sendo rara e não tem sido recoletada há mais de 100 anos nessa região.

Caracteriza-se principalmente pelo indumento furfuráceo-estrelado e glanduloso-granuloso, folhas com nervuras acródromas suprabasais e brácteas e profilos caducos. Aproxima-se de $L$. magdalenensis, L. gracilis e L. multisetosa pela presença de tricomas glanduloso-granulosos. Porém, distingui-se da primeira pela ausência de tricomas dendríticos nas partes vegetativas e no hipanto, e das outras duas espécies pelas nervuras acródromas foliares 2-5 mm suprabasais (vs. 6-30 mm) e brácteas e profilos caducos ( $v s$. persitentes).

Leandra sphaerocarpa Cogn. in A. \& C. De Candolle, Mon. Phan. 7: 676. 1891.

Fig. 8a-d

Arbustos a arvoretas 2-3 m alt., aparentemente glabros, com indumento inconspícuo glanduloso-pontoado e pubéruloglanduloso, tricomas cedo caducos. Folhas nitidamente anisófilas; pecíolo $0,7-1,7 \mathrm{~cm}$ compr.; lâmina 4-10,2 × (1,5-)2-3,7 cm, membranácea, elíptica a lanceolada, base aguda, margem inteira ou inconspícuo-ondulada, obscuramente cilioladoadpressa, tricomas esparsos, ápice acuminado, agudo ou agudo-atenuado; 3 nervuras acródromas 3-20 mm suprabasais, nervuras secundárias e de ordem superior inconspícuas. Tirsóides 3,5-6,5 cm compr., ramos capilariformes; brácteas 1,2-1,7 $\times$ $0,4-0,5 \mathrm{~mm}$, profilos ca. $1,5 \times 0,5-0,7 \mathrm{~mm}$, ambos linear-lanceolados, persistentes. Flores 5-meras; pedicelo 1-1,2 mm compr.; hipanto 1,7-2 × 1,8-2 $\mathrm{mm}$, levemente campanulado; zona do disco glabra; cálice com tubo ca. $0,2 \mathrm{~mm}$ compr, lacínias eretas a patentes, as externas ca. $1 \times 0,3 \mathrm{~mm}$, linearsubuladas, ápice agudo, as internas ca. 0,4 × 0,2 $\mathrm{mm}$, ovadas, ápice obtuso, quase totalmente unidas às externas; pétalas ca. 3,5 × 1-1,2 $\mathrm{mm}$, alvas, reflexas, oblongo-tringulares, ápice atenuadoacuminado, glabras; filetes ca. 1,5 mm compr.; anteras ca. $2 \times 0,7 \mathrm{~mm}$, alvas, ovadas, poro terminal, conectivo não prolongado, giboso na porção basal do dorso, inapendiculado, às vezes apêndice dorsal inconspícuo, truncado; ovário 1,4-1,5×0,5-0,6 mm, ínfero, 3-4-locular, glabro; estilete ca. $6 \mathrm{~mm}$ compr. Bacídios 5-7 mm compr., vinosos, subglobosos.

Material examinado: 21.X(XII).1887, fr., A.F.M. Glaziou 16916 (K, P, R, isosíntipos); 6.X.1888(1889), fl., A.F.M. Glaziou 17555 (BR, P, R, isosíntipos); 1888, fl., A.F.M. Glaziou s.n. (BR); 25.V.1987, fr., G. Martinelli et al. 12071 (FLOR, RB, US).
Endêmica da região de Macaé de Cima, em Nova Friburgo, tendo sido recoletada 118 anos após a coleção-tipo. É uma espécie rara e ocorre a ca. $1.000 \mathrm{~m}$ de altitude, no interior de mata de encosta, em local sombreado, margeando o rio das Flores.

Pode ser reconhecida pelo aspecto aparentemente glabro, mas com o indumento constituído de diminutos tricomas glandulares revestindo a superfície da planta de modo pontoado e, geralmente, de difícil visualização.

Leandra tetragona Cogn. in A. \& C. De Candolle, Mon. Phan. 7: 635. 1891. Fig. $8 \mathrm{e}$

Plantas nitidamente pilosas; indumento dos ramos e pecíolos densamente furfuráceo-estrelado, tricomas glanduloso-granulosos ausentes, os nós com tricomas dendríticos; ramos nitidamente tetragonais, subalados. Folhas isófilas ou anisófilas; pecíolo 4 $7,3 \mathrm{~cm}$ compr., tetragonal; lâmina 12-22×5,6-11,7 cm, cartácea, ovada, base arredondado-subcordada, margem crenulado-denticulada, estriguloso-ciliolada, ápice atenuado-acuminado, subfalcado, face adaxial densamente estriguloso-adpressa, nas nervuras acródromas denso-hirtela e furfuráceo-estrelada, face abaxial densamente tomentoso-dendrítica e moderadamente furfuráceo-estrelada; 5-7 nervuras acródromas 3-7 mm suprabasais, além de um par marginal inconspícuo apenas na base. Fruto jovem com hipanto 3-4 × ca. $3 \mathrm{~mm}$, moderadamente setuloso e densamente tomentoso-dendrítico; zona do disco glabra ou com esparsos tricomas furfuráceo-estrelados; cálice pentâmero, lacínias patentes a reflexas, as externas 2$2,5 \times$ ca. $1 \mathrm{~mm}$, triangulares, um tanto crassas, moderadamente setulosas e densamente tomentosodendríticas e -estreladas, as internas diminutas, estreitamente oblongo-ovadas, ápice arredondado, ambas as faces furfuráceo-estreladas; ovário moderadamente furfuráceo-estrelado; estilete ca. $5 \mathrm{~mm}$ compr. Frutos maduros não vistos.

Material examinado: 30.X.1887(1888), fl. e fr., A.F.M. Glaziou 16872 (BR, holótipo; P, R, isótipos).

Endêmica da região de Macaé de Cima, em Nova Friburgo, é uma espécie rara e não tem sido recoletada há mais de 120 anos. Em virtude da escassez de material reprodutivo para análise, características do cálice, hipanto e estilete foram complementadas com base nos dados de Cogniaux (1891). Neste trabalho, o autor enquadra L. tetragona na seção Carassanae e próxima de $L$. dasytricha, porém, pela morfologia foliar aproxima-se também de L. carassana. Nos comentários destas espécies já foi abordada a afinidade entre esses três táxons, em que L. tetragona se diferencia pelos ramos nitidamente tetragonais e subalados. 


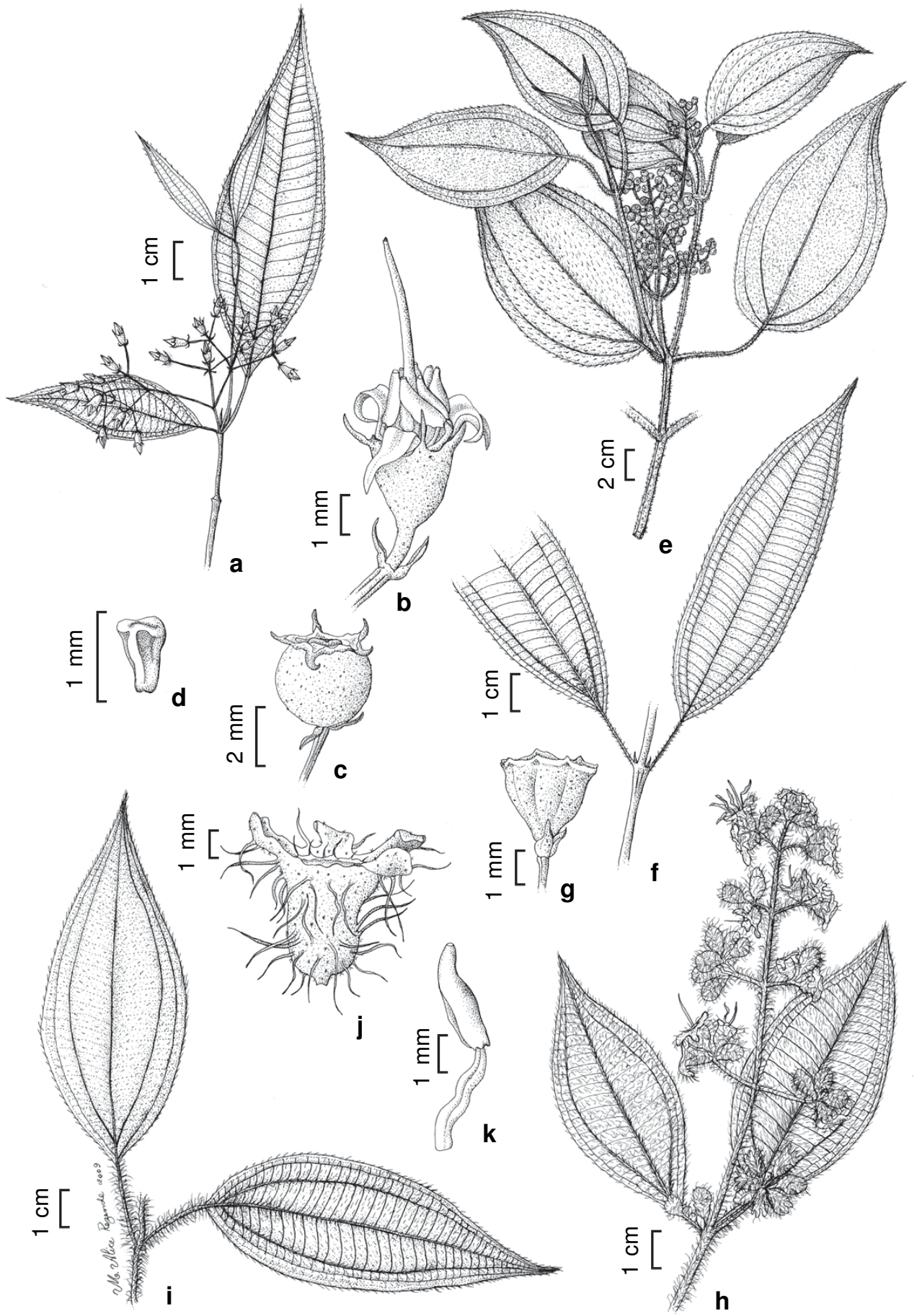

Figura 8-a-d. Leandra sphaerocarpa (DC.) Cogn. - a. ramo florífero; b. flor; c. fruto jovem; d. semente. e. Leandra tetragona Cogn. - ramo florífero. f-g. Leandra truncata Baumgratz \& D'El Rei Souza - f. folhas; g. fruto jovem e profilos. h. Leandra xanthocoma (Naudin) Cogn. - ramo florífero. i-k. Leandra xanthostachya Cogn. - i. folhas; j. fruto jovem; k. estame. (a Glaziou 17555; b-d Glaziou 16916; e Glaziou 16872; f-g Souza \& Baumgratz 1498; h Brade 16155; i-k Baumgratz et al. 502).

Figure 8 - a-d. Leandra sphaerocarpa (DC.) Cogn. - a. flowering branch; b. flower; c. young fruit; d. seed. e. Leandra tetragona Cogn. - flowering branch. f-g. Leandra truncata Baumgratz \& D’El Rei Souza - f. leaves; g. young fruit and prophylls. h. Leandra xanthocoma (Naudin) Cogn. - flowering branch. i-k. Leandra xanthostachya Cogn. - i. leaves; j. young fruit; k. stamen. 
Leandra truncata Baumgratz \& D'El Rei Souza, Acta bot. bras. 19(3): 574, fig. 1.2005. Fig. 8f-g

Arbustos ca. 1,5 m alt., aparentemente glabros; indumento dos ramos, folhas, inflorescências, hipanto e cálice esparsa a densamente glanduloso-granuloso, tricomas diminutos, caducos ou não. Folhas com pecíolo $1,1-3,5$ cm compr.; lâmina 8,7-17,5 ×2,3-4,4 cm, membranácea a papirácea, elíptica ou estreitoobovada ou -ovada, às vezes oblonga, base cuneada a aguda, às vezes curto-decorrente, margem serrulado- e ondulado-ciliolada, às vezes revoluta, ápice agudo, acuminado, atenuado ou caudado, face abaxial também esparsa a moderadamente setulosa e setulosoglandulosa nas nervuras acródromas, cabeça glandular caduca; domácias ausentes; $3(-5)$ nervuras acródromas $2-10 \mathrm{~mm}$ suprabasais, par marginal tênue. Tirsóides; brácteas e profilos persistentes. Flores 5-meras; hipanto 2,2-2,5 mm compr.; zona do disco inconspícuodenticulada, glabra; cálice truncado-ondulado a -denticulado, com tubo 0,2-0,3 mm compr., lacínias eretas, as externas $0,08-0,3 \times$ ca. $0,2 \mathrm{~mm}$, denticulado-triangulares, gibosas, ápice acuminado, as internas 0,2-0,4 $\mathrm{mm}$ compr., oblato-triangulares, margem glandulosogranulosa; pétalas 3,5-3,7 mm compr., reflexas, elípticas, ápice atenuado, glabras; filetes 2,7$3 \mathrm{~mm}$ compr.; anteras 1,8-2 mm compr., elípticas ou obovadas, cuneadas ou não, conectivo giboso, prolongado ou não, inapendiculado; ovário 1/3-ínfero, 3-locular, glabro; estilete 6,8$7 \mathrm{~mm}$ compr. Frutos maduros não vistos.

Material examinado: 20.XII.1994, fl., M.L. Souza \& J.F.A. Baumgratz 1498 (CEPEC, FLOR, RB, SPF).

Endêmica do Brasil, com ocorrência restrita ao Rio de Janeiro e São Paulo, em formações florestais de altitude, incluindo matas nebulares e com araucárias (Baumgratz \& Souza 2005). Na Reserva, é encontrada em torno de $1.100 \mathrm{~m}$ de altitude, crescendo em local sombreado de mata de encosta ao longo da estrada para o Sítio Sophronites. É uma espécie rara na área, sendo sua coleta o primeiro registro para o estado fluminense. Baumgratz \& Souza (2005) assinalaram ser endêmica das regiões montanhosas de Campos do Jordão, em São Paulo.

Aproxima-se de L. barbinervis e $L$. quinquedentata, conforme abordado nos comentários destas espécies.
Leandra xanthocoma (Naudin) Cogn. in Mart., Eichler \& Urban, Fl. bras. 14(4): 124-125. 1886.

Fig. $8 \mathrm{~h}$

Subarbustos ca. $40-80 \mathrm{~cm}$ alt., nitidamente pilosos; indumento dos ramos, pecíolos e inflorescências moderadamente hirsuto a hirtelo e furfuráceo-estrelado, amarelado, tricomas glandulosogranulosos ausentes; ramos achatados a subcilíndricos, nunca alados. Folhas com pecíolo 1,5$1,8 \mathrm{~cm}$ compr.; lâmina 4-9 × 2,4-4,5 cm, plana, papirácea, elíptica ou ovada, base arredondada ou obtusa, não decorrente nem agudo-cuneada, margem ondulado-ciliolada, ápice agudo, atenuado ou acuminado, face adaxial moderadamente setuloso- a setoso-adpressa, face abaxial moderadamente setosovilosa e esparsa a moderadamente furfuráceoestrelada; 5 nervuras acródromas $2-5 \mathrm{~mm}$ suprabasais. Tirsóides; brácteas e profilos persistentes. Flores 5meras; hipanto 5-5,2 mm compr., hirsuto- a hirteloviloso e furfuráceo-estrelado; zona do disco setulosa, anel membranáceo ausente; lacínias do cálice reflexas, as externas 3-5,5 mm compr., as internas 1-2,2 $\mathrm{mm}$ compr.; pétalas ca. $5 \mathrm{~mm}$ compr., reflexas, oblongotriangulares, ápice agudo, glabras; filetes ca. 4,5 mm compr.; anteras 4,5-6 mm compr., amarelas, linearlanceoladas, conectivo não prolongado, apêndice inconspícuo, truncado ou bilobado, às vezes com projeções ventrais; ovário 2/3-3/5-ínferos, 3-4locular, glabro ou piloso; estilete $14,8-15 \mathrm{~mm}$ compr. Frutos maduros não vistos.

Material examinado: 16.I.1991, fl. e fr., J.F.A. Baumgratz et al. 520 (RB); 16.I.1991, fl., J.F.A. Baumgratz et al. 521 (RB); 16.I.1991, fl. e fr., J.F.A. Baumgratz et al. 525 (FLOR, RB); 2.V.2001, fr., R.A.M. Tavares et al. 88 (RB).

Material adicional examinado: BRASIL. RIO DE JANEIRO: Petrópolis, Cremerie, XII.1939, fl., A.C. Brade 16155 (RB).

Distribui-se no Brasil, pelos estados de Minas Gerais, Rio de Janeiro, São Paulo, Paraná e Santa Catarina, e também na Argentina e Uruguai. Na Reserva, foi coletada ao longo da estrada para o Hotel Fazenda São João, entre 900-1.000 m de altitude, geralmente em locais abertos e ensolarados, nas margens e clareiras naturais no interior de mata de encosta. Na natureza, a cor amarelada do indumento auxilia no reconhecimento da espécie.

Leandra xanthostachya Cogn. in Mart., Eichler \& Urban, Fl. bras. 14(4): 93, t. 20. $1886 . \quad$ Fig. 8i-k

Subarbustos a arbustos $0,4-1,5 \mathrm{~m}$ alt., nitidamente pilosos; indumento dos ramos, pecíolos, inflorescências e hipanto moderada a densamente hirsuto, tricomas 3-7,5 mm compr., 
frequentemente amarelos, e furfuráceo-estrelado, estes caducos, tricomas glanduloso-granulosos ausentes; ramos subcilíndricos a cilíndricos, nunca alados. Folhas com pecíolo 1-3,5 cm compr.; lâmina 5,8-13,5 ×2,3-6 cm, plana, membranácea a rígido-membranácea, ovada ou elíptica, base obtusa ou arredondada, não decorrente nem agudocuneada, margem crenulado-ciliolada, ápice atenuado ou atenuado-acuminado, ambas as faces moderadamente setuloso-setosas e furfruráceoestreladas, estes tricomas caducos; 5-7 nervuras acródromas 5-11 mm suprabasais. Tirsóides; brácteas e profilos persistentes. Flores 5-meras; hipanto 2,8-4,2 mm compr.; zona do disco esparsosetulosa, anel membranáceo ausente; lacínias do cálice patentes a reflexas, as externas 1-2(-3) $\mathrm{mm}$ compr., as internas 1-1,5 mm compr.; pétalas 3$3,8 \mathrm{~mm}$ compr., reflexas, oblongo-triangulares, ápice atenuado, às vezes curto-apiculadas, glabras; filetes 2,3-2,7 mm compr.; anteras 2,1-3 mm compr., amarelas, oblongas a lanceoladas, conectivo às vezes levemente giboso, não prolongado, inapendiculado ou apêndice inconspícuo, agudo; ovário 1/2-3/4-ínferos, 3-4-locular, glabro ou esparso-setuloso; estilete 5,8-8,5 $\mathrm{mm}$ compr. Bacídios 5.5-7 mm compr.

Material examinado: 30.X.1887, fl., A.F.M. Glaziou 16837 (P, R); 27.XI.1986, fl., J.F.A. Baumgratz et al. 380 (CEPEC, FLOR, RB); 27.XI.1986, fl. e fr., J.F.A. Baumgratz et al. 381 (FLOR, RB, US); 7.XI.1988, fr., R. Guedes et al. 2193 (RB); 8.XII.1988, fl. e fr., S.V.A. Pessoa et al. 435 (FLOR, RB, SPF); 20.XI.1990, fl., J.F.A. Baumgratz et al. 487 (FLOR, RB); 21.XI.1990, fl., J.F.A. Baumgratz et al. 499 (RB); 21.XI.1990, fl., J.F.A. Baumgratz et al. 501, 504 (RB); 21.XI.1990, fl. e fr., J.F.A. Baumgratz et al. 503 (FLOR, RB); 21.XI.1990, fl., J.F.A. Baumgratz et al. 502 (CEPEC, RB); 16.I.1991, fl. e fr., J.F.A. Baumgratz et al. 531 (RB); 17.I.1991, fr., J.F.A. Baumgratz et al. 535 (FLOR, MBM, RB); 17.I.1991, fr., J.F.A. Baumgratz et al. 549 (RB); 20.XII.1994, fl., M.L. Souza \& J.F.A. Baumgratz 1490 (FLOR, RB); 20.XII.1994, fl. e fr., M.L. Souza \& J.F.A. Baumgratz 1492 (FLOR, RB); 1.V.2001, fr., R.A.M. Tavares et al. 77 (RB); 14.XII.2001, fl. e fr., R.A.M. Tavares et al. 101 (RB).

Endêmica do Brasil, ocorrendo em Minas Gerais, Rio de Janeiro, São Paulo, Paraná e Santa Catarina, geralmente em locais de altitude. $\mathrm{Na}$ Reserva, ocorre em áreas do entorno dos Sítios Bacchus e Sophronites e do Hotel Fazenda São João, entre 850-1.360 m de altitude, em locais geralmente ensolarados, às vezes sombreados, em matas de encostas e ao longo de estradas e trilhas.

Espécie muito semelhante vegetativamente a L. nianga, conforme abordado nos comentários desta espécie.
No espécime Souza \& Baumgratz 1490, os tricomas das inflorescências apresentam uma coloração avermelhada, o que não é usual para a espécie, pois são normalmente amarelados. Possivelmente, é em virtude de estar num local mais sombreado.

O estudo de Leandra na Reserva Ecológica de Macaé de Cima atualiza as informações já divulgadas para a Reserva e possibilita elucidar dúvidas quanto a coleções de A.F.M. Glaziou, principalmente em relação a dados contidos nas etiquetas que se mostram controversos, como já mencionado por Wurdack (1970).

Assinala-se um total de 18 novos táxons de Leandra para Macaé de Cima, resultante de inventários florísticos realizados na região a partir de 1988 (Lima \& Guedes-Bruni 1994), das listagens preliminares geradas com base nesses levantamentos (Baumgratz 1994, 1997; Baumgratz et al. 2001) e no presente estudo taxonômico.

Apesar de todo o empenho empreendido, algumas espécies ainda continuam sendo representadas para Macaé de Cima apenas por coleções-tipo, como L. aspera, $L$. atroviridis e $L$. tetragona. Estas, juntamente com L. altomacaensis, $L$. regnellii e $L$. riedeliana não têm sido coletadas nessa região há mais de 100 anos; já L. atroviridis e L. riedeliana são as únicas ainda não documentadas em um herbário nacional com amostras dessa região.

Entre as 35 espécies de Leandra reconhecidas, L. aspera, L. atroviridis, L. eriocalyx, L. laxa, L. mollis, L. multisetosa, L. sphaerocarpa e L. tetragona são endêmicas de Macaé de Cima e, juntamente com L. altomacaensis, L. breviflora, L. hirta var. hirta e L. magdalenensis, endêmicas do estado do Rio de Janeiro.

Para o estado fluminense, destacam-se como espécies raras $L$. aspera, $L$. atroviridis, $L$. eriocalyx, $L$. riedeliana, $L$. sphaerocarpa, $L$. tetragona e $L$. truncata. Supõe-se que esse grupo, incluindo $L$. altomacaensis e L. regnellii, ocorra na Reserva de modo muito esparso e/ou em locais de difícil acesso ou que tenham desaparecido em virtude das alterações na vegetação original decorrentes das atividades antrópicas na região.

Leandra altomacaensis, conforme assinalado por Baumgratz \& Souza (2009a), L. glazioviana, L. riedeliana e $L$. truncata representam novas ocorrências para a Reserva, além de L. regnellii, pois esta foi citada sob o nome L. schwackei (Glaziou 1908).

Leandra aspera, L. atroviridis, L. multisetosa, L. sphaerocarpa e L. tetragona estão sendo ilustradas pela primeira vez. 


\section{Agradecimentos}

Aos curadores dos herbários citados, os empréstimos concedidos e envio de fotografias ou imagens. Ao Programa Mata Atlântica (PMA/JBRJ), o apoio durante o desenvolvimento desse estudo. À ilustradora Maria Alice Rezende, a elaboração dos desenhos e pranchas. Ao CNPq, a bolsa de Produtividade em Pesquisa, e à Fundação de Amparo à Pesquisa do Estado do Rio de Janeiro (FAPERJ), o apoio financeiro à pesquisa, concedidos ao segundo autor.

\section{Referências}

Baumgratz, J.F.A. 1985. Morfologia dos frutos e sementes de Melastomataceae brasileiras. Arquivos do Jardim Botânico do Rio de Janeiro 27: 113-155.

Baumgratz, J.F.A. 1994. Melastomataceae: listagem. In: Lima, M.P.M. \& Guedes-Bruni, R. (orgs.). Reserva Ecológica de Macaé de Cima, Nova Friburgo, RJ: aspectos florísticos das espécies vasculares. Vol. 1. Jardim Botânico do Rio de Janeiro, IBGE, Rio de Janeiro. Pp. 39-40.

Baumgratz, J.F.A. 1997. Melastomataceae: listagem. In: Lima, H.C. \& Guedes-Bruni, R.R. (orgs). Serra de Macaé de Cima: diversidade florística e conservação em Mata Atlântica. Jardim Botânico do Rio de Janeiro, Rio de Janeiro. Pp. 331-332.

Baumgratz, J.F.A. \& Souza, M.L.D.R. 2005. Duas novas espécies de Leandra Raddi (Melastomataceae) para o Estado de São Paulo, Brasil. Acta Botanica Brasilica 19: 573-578.

Baumgratz, J.F.A. \& Souza, M.L.D.R. 2007. A new species of Leandra (Melastomataceae) from Brazil. Systematic Botany 32: 743-747.

Baumgratz, J.F.A. \& Souza, M.L.D.R. 2009a. Leandra altomacaensis (sect. Oxymeris), a new endemic species of Melastomataceae from Rio de Janeiro, Brazil. Kew Bulletin 64: 167-170.

Baumgratz, J.F.A. \& Souza, M.L.D.R. 2009b. Notas taxonômicas em Leandra (Melastomataceae) - II. Bradea 14: 1-10.

Baumgratz, J.F.A. \& Souza, M.L.D.R. 2009c. Melastomataceae: Leandra Raddi. In: Wanderley, M.G.L.; Shephered, G.J.; Melhem, T.S.; Giulietti, A.M. \& Martins, S.E. (eds.). Flora fanerogâmica do estado de São Paulo. Vol. 6. Ed. Impressa Oficial, São Paulo. Pp. 32-68.

Baumgratz, J.F.A.; Souza, M.L.D.R. \& Tavares, R.A.M. 2001. In: Lima, H.C.; Morim, M.P.; Guedes-Bruni, R.R.; Sylvestres, L.S.; Pessoa, S.V.A.; Silva Neto, S. \& Quinet, A. (orgs.). Reserva Ecológica de Macaé de Cima, Nova Friburgo, RJ: Lista de espécies vasculares. Disponível em <http:/graziela.jbrj.gov.br/pesquisa/

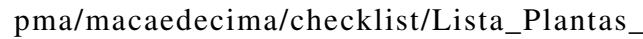
Vasculares_apresentacao.htm>. Acesso em Jul 2008.
Baumgratz, J.F.A.; Souza, M.L.D.R. \& Tavares, R.A.M. 2007. Melastomataceae na Reserva Ecológica de Macaé de Cima, Nova Friburgo, Rio de Janeiro, Brasil. I - Tribos Bertolonieae, Merianieae e Microlicieae. Rodriguésia 58: 797-822.

Briggs, B.G. \& Johnson, L.A.S. 1979. Evolution in the Myrtaceae-evidence from inflorescence structure. Proceedings of the Linnean Society of New South Wales 102: 157-256.

Camargo, E.A. \& Goldenberg, R. 2007. O gênero Leandra, seção Leandraria (Melastomataceae) no Paraná. Iheringia - série Botânica 62: 105-113.

Camargo, E.A.; Souza, C.M.F.; Caddah, M.K. \& Goldenberg, R. 2009. O gênero Leandra, seções Carassanae, Chaetodon, Niangae, Oxymeris e Secundiflorae (Melastomataceae) no estado do Paraná. Rodriguésia 60: 595-631.

Clausing, G. \& Renner, S.S. 2001. Molecular phylogenetics of Melastomataceae and Memecylaceae: implications for character evolution. American Journal of Botany 88: 486-498.

Cogniaux, A. 1886. Leandra. In: Martius, C.F.P.; Eichler, A.G. \& Urban, I. (eds.). Flora brasiliensis. Lipsiae Frid. Fleischer, Monachii, 14: 66-209.

Cogniaux, A. 1888. Addenda et Emendanda - Leandra. In: Martius, C.F.P.; Eichler, A.G. \& Urban, I. (eds.). Flora brasiliensis. Monachii, Lipsiae Frid. Fleischer, 14: 606-611.

Cogniaux, A. 1891. Melastomaceae. In: Candolle, A. \& Candolle, C. (eds.). Monographiae Phanerogamarum. Vol. 7. G. Masson, Paris. 1256p.

Glaziou, A.F.M. 1908. Plantae Brasiliae centralis a Glaziou lectae - Liste des plantes du Brésil Central recueillies en 1861-1895: Mélastomacées. Bulletin de la Société Botanique de France, Mémoires 1: 201-296.

Gröger, A. 2001. Leandra Raddi. In: Berry, P.E.; Yatskievych, K.Y. \& Holst, B.K. (eds.). Flora of the Venezuelan Guayana. Vol. 6. Missouri Botanical Garden Press, St. Louis. Pp. 350-362.

Guedes-Bruni, R. \& Lima, M.P.M. 1994. Abordagem geográfica, fitofisionômica, florística e taxonômica da Reserva Ecológica de Macaé de Cima. In: Lima, M.P.M. \& Guedes-Bruni, R. (orgs.). 1994. Reserva Ecológica de Macaé de Cima, Nova Friburgo, RJ: aspectos florísticos das espécies vasculares. Vol. 1. Jardim Botânico do Rio de Janeiro, IBGE, Rio de Janeiro. Pp. 17-54.

Holmgren, P.K.; Holmgren, N.H. \& Barnett, L.C. 1990. Index Herbariorum. Part. I: The herbaria of the world. Regnum vegetabile. $8^{\text {a }}$ ed. New York Botanical Garden, New York. 693p.

Judd, W.S. \& Skean, J.D. 1991. Taxonomic studies in the Miconiae (Melastomataceae). IV. Generic realignements among terminal-flowered taxa. Bulletin of the Florida Museum of Natural History, Biological Sciences 36: 25-84. 
Lima, H.C. \& Guedes-Bruni, R. (eds.). 1997. Serra de Macaé de Cima: diversidade florística e conservação em Mata Atlântica. Jardim Botânico do Rio de Janeiro, Rio de Janeiro. 345p.

Lima, M.P.M. \& Guedes-Bruni, R. (orgs.). 1994. Reserva Ecológica de Macaé de Cima, Nova Friburgo, RJ: aspectos florísticos das espécies vasculares. Vol. 1. Jardim Botânico do Rio de Janeiro, IBGE, Rio de Janeiro. 404p.

Lucena, I.D. 1983. Las especies argentinas de Leandra. Lilloa 36: 43-58. 1983.

Martin, C.V.; Little, D.P.; Goldenberg, R. \& Michelangeli, F.A. 2008. A preliminary phylogenetic analysis of the polyphyletic genus Leandra (Miconieae, Melastomataceae). Cladistics 24: 315-327.

Radford, A.E.; Dickison, W.C.; Massey, J.R. \& Bell, C.R. 1974. Vascular plant systematics. Harper \& Row Pub., New York. 891p.

Rambo, B. 1966. Melastomataceae Riograndenses. Pesquisas 22: 1-48.

Renner, S.S. 1993. Phylogeny and classification of the Melastomataceae and Memecylaceae. Nordic Journal of Botany 13: 519-540.

Romero, R. 1993. Florística da família Melastomataceae na planície litorânea de Pincinguaba. município de Ubatuba, Parque Estadual da Serra do Mar, SP. Dissertação de Mestrado. Universidade Estadual Paulista, Rio Claro. 178p.

Souza, M.L.D.R. \& Baumgratz, J.F.A. 2004. Notas taxonômicas em Leandra Raddi (Melastomataceae). Insula 33: 89-99.
Souza, M.L.D.R. \& Baumgratz, J.F.A. 2009. Melastomataceae: Leandra. In: Martins, S.E.; Wanderley, M.G.L.; Shepherd, G.J; Melhem, T.S. \& Giulietti, A.M. (eds.). Flora fanerogâmica do estado de São Paulo. Vol. 6. Instituto de Botânica, FAPESP, São Paulo. Pp. 32-68.

Souza, M.L.D.R. \& Baumgratz, J.F.A. 2010. Melastomataceae: Leandra. In: Forzza, R.C.; Baumgratz, J.F.A.; Bicudo, C.E.M.; Carvalho Jr., A.A.; Costa, A.; Costa, D.P.; Hopkins, M.; Leitmann, P.M.; Lohmann, L.G.; Maia, L.C.; Martinelli, G.; Menezes, M.; Morim, M.P.; Coelho, M.A.N.; Peixoto, A.L.; Pirani, J.R.; Prado, J.; Queiroz, L.P.; Souza, V.C.; Stehmann, J.R.; Sylvestre, L.S.; Walter, B.M.T. \& Zappi, D. (orgs.). Catálogo de plantas e fungos do Brasil. Vol. 2. Andrea Jakobsson Estúdio Editorial/Jardim Botânico do Rio de Janeiro, Rio de Janeiro. Pp. 1245-1252.

Weberling, F. 1988. The architeture of inflorescences in the Myrtales. Annals of the Missouri Botanical Garden 75: 226-310.

Weberling, F. 1989. Morphology of flowers and inflorescences. Cambridge University Press, New York. 405p.

Wurdack, J.J. 1962. Melastomataceae of Santa Catarina. Sellowia 14: 109-217.

Wurdack, J.J. 1970. Erroneous data in Glaziou collections of Melastomataceae. Taxon 19: 911-913. 